\title{
Synthesis, Mechanism of Action, and Biological Evaluation of Mitosenes
}

\author{
E. O. M. Orlemans, ${ }^{\dagger}$ W. Verboom, ${ }^{\dagger}$ M. W. Scheltinga,${ }^{\dagger}$ D. N. Reinhoudt, ${ }^{*}{ }^{\dagger}$ P. Lelieveld, ${ }^{\ddagger}$ H. H. Fiebig, ${ }^{\S}$
}

B. R. Winterhalter, ${ }^{\S}$ J. A. Double, and M. C. Bibby

Laboratory of Organic Chemistry, University of Twente, P.O. Box 217, 7500 AE Enschede, The Netherlands, Radiobiological Institute TNO, P.O. Box 5815, $2280 \mathrm{HV}$ Rijswijk, The Netherlands, Medizinische Universität Klinik, Hugstetter Strasse 55, 7800 Freiburg, Federal Republic of Germany, and Clinical Oncology Unit, University of Bradford, Bradford,

West Yorkshire BD7 1DP, England. Received September 22, 1988

\begin{abstract}
Mitosenes of both the pyrrolo- and pyrido[1,2-a]indole type have been prepared via modification of these heterotricyclic compounds. Several mitosenes have been studied for their reactions with nucleophiles under reductive conditions. The results of these experiments show that the biological activity of mitosenes is based on the mechanism of bioreductive activation. When both leaving groups at C-1 and C-10 in the mitosene are the same, the nucleophile preferably adds to $\mathrm{C}-10$ under reductive conditions. All mitosenes were studied for their biological activities in vitro against $\mathrm{L} 1210, \mathrm{WiDr}$, and A204. On the basis of these results a selection of three mitosenes was made for a more detailed biological evaluation. Several tumor model systems were used, viz. P388, human tumor xenografts, MAC 13, and MAC 16. The results of these studies show that mitosenes have a more limited range of activities than mitomycin C. Surprisingly, the in vivo activities of mitosene diol $\mathbf{8 b}$ and mitosene diacetate $\mathbf{1 0 b}$ against the gastric human tumor xenograft GXF 97 were very high and comparable with that of mitomycin C.
\end{abstract}

The mitomycins are an important class of heterotricyclic antitumor antibiotics. ${ }^{1,2}$ However, the clinical use of mitomycin $\mathrm{C}(\mathrm{MMC}, 1)$ is limited by its toxicity. ${ }^{3}$ In fact, MMC is a prodrug that is metabolically activated by reduction or acidification. 4,5 The one-electron reduction of $\mathrm{MMC}$ and the subsequent expulsion of the C-9a methoxy substituent assisted by the nitrogen lone pair yields a reduced mitosene. ${ }^{6}$ This mitosene intermediate is a bifunctional alkylating agent capable of cross-linking DNA. ${ }^{4}$ Furthermore, it has been shown that chemically and enzymatically activated reduction of MMC in the presence of various nucleophiles produce, after oxidation, adducts with the nucleophile covalently linked at $\mathrm{C}-1,{ }^{7}$ or both $\mathrm{C}-1$ and $\mathrm{C}-10{ }^{4 b, c, 8}$
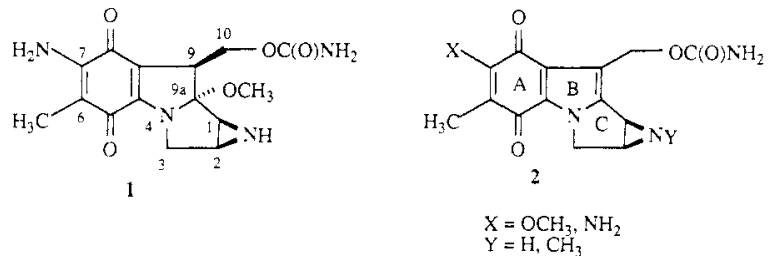

Since reduced mitosenes are the active intermediates in the bioreductive activation process, the synthesis of mitosenes has received considerable attention. ${ }^{9}$ In addition, both synthetic and semisynthetic mitosenes, containing suitably good leaving groups, have been tested for their biological activity ${ }^{10}$ The results of the biological evaluations performed by Remers et al. ${ }^{10 a, c, d}$ revealed that mitosenes have good activities against P388 leukemia, giving prolongation of life span comparable to that of MMC, but at higher optimal doses. Furthermore, it was demonstrated that leaving groups at $\mathrm{C}-1$ and $\mathrm{C}-10$ were necessary for significant antitumor activity. However, these authors also stated that the effect of different leaving groups on the biological activity was difficult to interpret. When inactivity was noted, it was attributed to steric factors and/or excess of lipophilicity. Alternatively, the leaving groups may be too reactive and may be hydrolyzed or undergo a nonspecific alkylation before reaching the target DNA.

Studies on the relationship between structural modifications in mitosenes and their antitumor activity have included variations of the 6-and 7-substituent of the

\footnotetext{
${ }^{+}$University of Twente.

‡ Radiobiological Institute TNO.

$\S$ Medizinische Universität Klinik.

" University of Bradford.
}

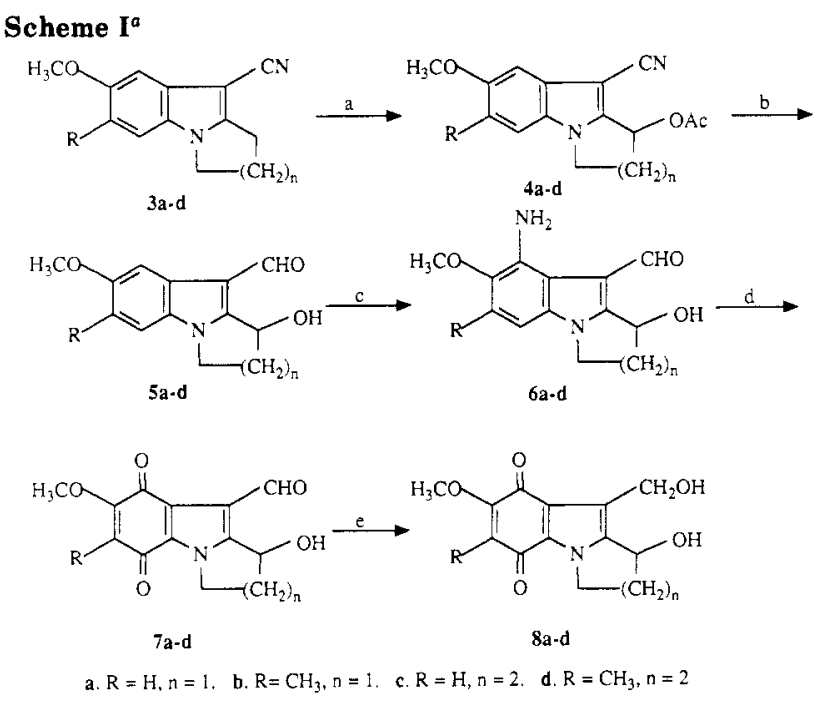

a (a) $\mathrm{Pb}(\mathrm{OAc})_{4} / \mathrm{HOAc}$; (b) $1, \mathrm{NaOMe} / \mathrm{MeOH} ; 2, \mathrm{Ni}-\mathrm{Al} / 50 \%$ $\mathrm{HOAc} / 140^{\circ} \mathrm{C}$; (c) $1,65 \% \mathrm{HNO}_{3} ; 2, \mathrm{Sn} / \mathrm{HCl}$; (d) Fremy's salt; (e) $1, \mathrm{H}_{2} / 5 \% \mathrm{Pd} / \mathrm{C} ; 2, \mathrm{NaBH}_{4} / \mathrm{MeOH} ; 3, \mathrm{FeCl}_{3}$.

quinone ring, the carbamate function, and the aziridine ring. ${ }^{10 a, c, d}$ However, one structural feature not investigated

(1) (a) Remers, W. A. In Anticancer Agents Based on Natural Product Models; Academic Press: New York, 1980; Chapter 5, p 131. (b) Crooke, S. T. In Mitomycin C-Current Status and New Developments; Carter, S. K., Crooke, S. T., Eds.; Academic Press: New York, 1979.

(2) (a) Crooke, S. T. Cancer Chemotherapy; Academic Press: New York, 1981; Vol. 3, p 49. (b) Nakano, K. Heterocycles $1979,13,373$

(3) Reference $1 \mathrm{~b}, \mathrm{p} 33$.

(4) (a) Iyer, V. N.; Szybalski, W. Science 1964, 145, 55. (b) Tomasz, M.; Lipman, R.; Chowdary, D.; Pawlak, J.; Verdine, G. L.; Nakanishi, K. Science 1987, 235, 1204, and references cited therein. (c) Tomasz, M.; Chawla, A. K.; Lipman, R. Biochemistry 1988, 27, 3182 .

(5) (a) Lown, J. W.; Weir, G. Can. J. Chem. 1978, 56, 296. (b) Lown, J. W.; Begleiter, A.; Johnson, D.; Morgan, A. R. Can. J. Chem. 1976, 54, 110. (c) Tomasz, M.; Lipman, R.; Lee, M. S.; Verdine, G. L.; Nakanishi, K. Biochemistry 1987, 26, 2010.

(6) See for instance: (a) Andrews, P. A.; Pan, S.-S.; Bachur, N. R J. Am. Chem. Soc. 1986, 108, 4158. (b) Rao, G. M.; Begleiter, A.; Lown, J. W.; Plambeck, J. A. J. Electrochem. Soc. 1977, 124, 199. (c) Kohn, H.; Zein, N.; Lin, X. Q.; Ding, J.-Q.; Kadish, K. M. J. Am. Chem. Soc. 1987, 109, 1833. (d) Danishefsky, S. J.; Egbertson, M. J. Am. Chem. Soc. 1986, 108, 4648. 
thus far is the variation of the size of ring $\mathrm{C}$ in the mitosene skeleton. Furthermore, to the best of our knowledge, the reductive activation of mitosenes has never been studied in detail. This is in contrast with investigations concerning the mechanism of the reductive activation of MMC itself, which has received considerable attention. ${ }^{4 b, c, 7,8}$ It should be mentioned that recently one report has appeared dealing with reduction experiments of indoloquinones. ${ }^{11}$

Therefore, the main objectives of the work described in this paper ${ }^{12 a}$ involve (i) a study concerning a variation in the size of ring $\mathrm{C}$ in the mitosene skeleton and its effect on the antitumor activity, and (ii) an investigation of the activation of mitosenes under reductive conditions in the presence of nucleophiles.

\section{Chemistry}

Synthetic routes to mitosenes, containing a large variation of substituents, with the objective to study the effect of these modifications on the antitumor activity are well documented.10d In this paper the 2,3-dihydro- $1 H$ pyrrolo[1,2-a]indoles $\mathbf{3} \mathbf{a}, \mathbf{b}$ and the $6,7,8,9$-tetrahydropyrido[1,2-a]indoles $\mathbf{3 c}, \mathbf{d}$ were obtained by using our modified Madelung indole synthesis, i.e. the intramolecular condensation of $\mathrm{N}$-acylated $o$-alkylanilines, that we have described previously. ${ }^{12 b}$ The heterotricyclic compounds 3 were converted into the corresponding acetyloxylated carbonitriles 4 with lead tetraacetate in acetic acid ${ }^{13}$ (Scheme I). The carbonitriles 4 were subsequently treated with sodium methoxide followed by reduction of the nitrile moiety with nickel-aluminum alloy ${ }^{14,15}$ in $50 \%$ aqueous acetic acid at $140^{\circ} \mathrm{C}$ to give the hydroxy carboxaldehydes 5. The quinone function was easily introduced in the compounds 5 by standard methodology, viz. nitration, reduction of the nitro group, and oxidation using potassium nitrosodisulfonate (Fremy's salt). ${ }^{15}$ Reduction of the aldehyde moiety in 7 to the corresponding alcohols 8 provided at first a problem, because upon treatment with sodium borohydride overreduction took place. ${ }^{16}$ However,

(7) See for instance: (a) Tomasz, M.; Lipman, R.; Lee, M. S.; Verdine, G. L.; Nakanishi, K. Biochemistry 1986, 25, 4337. (b) Bean, M.; Kohn, H. J. Org. Chem. 1985, 50, 293. (c) Hornemann, U.; Keller, P. J.; Kozlowski, J. F. J. Am. Chem. Soc. 1979, 101, 7121. (d) Hashimoto, Y.; Shudo, K.; Okamoto, T. Chem. Pharm. Bull. 1983, 31, 861. (e) Tomasz, M.; Lipman, R. Biochemistry 1981, 20, 5056.

(8) (a) Hornemann, U.; Iguchi, K.; Keller, P. J.; Vu, H. M.; Kozlowski, J. F.; Kohn, H. J. Org. Chem. 1983, 48, 5026. (b) Zein, N.; Kohn, H. J. Am. Chem. Soc. 1986, 108, 296.

(9) For reviews, see among others: (a) Takahaski, K.; Kametani, T. Heterocycles 1979, 13, 411. (b) Verboom, W.; Reinhoudt, D. N. Recl. Trav. Chim. Pays-Bas 1986, 105, 199.

(10) (a) Iyengar, B. S.; Remers, W. A.; Bradner, W. T. J. Med. Chem. 1986, 29, 1864, and references cited therein. (b) Kojima R.; Driscoll, J.; Mantel, N.; Goldin, A. Cancer Chemother. Rep. 1972, 39, 121. (c) Hodges, J. C.; Remers, W. A.; Bradner, W. T. J. Med. Chem. 1981, 24, 1184. (d) Casner, M. L.; Remers, W. A.; Bradner, W. T. J. Med. Chem. 1985, 28, 921, and references cited therein.

(11) Oostveen, E. A.; Speckamp, W. N. Tetrahedron 1987, 43, 225.

(12) (a) A part of this work has been published as a preliminary communication; see: Verboom, W.; Reinhoudt, D. N.; Lammerink, B. H. M.; Orlemans, E. O. M.; van Veggel, F. C. J. M.; Lelieveld, P. Anti-Cancer Drug Des. 1987, 2, 271. (b) Verboom, W.; Orlemans, E. O. M.; Berga, H. J.; Scheltinga, M. W.; Reinhoudt, D. N. Tetrahedron 1986, 42, 5053.

(13) Kametani, T.; Takahashi, K.; Kigawa, Y.; Ihara, M.; Fukumoto, K. J. Chem. Soc., Perkin Trans. 1 1977, 28.

(14) We were not able to convert the nitrile moiety into the corresponding aldehyde with diisobutylaluminum hydride.

(15) See for instance: Kametani, T.; Takahashi, K.; Ihara, M.; Fukumoto, K. J. Chem. Soc., Perkin Trans. 1 1976, 389.

(16) A similar overreduction has been reported earlier; see ref $10 \mathrm{~d}$. a selective conversion of aldehydes 7 into diols 8 could be accomplished by catalytic hydrogenation of quinones 7 with $5 \%$ palladium on charcoal $(\mathrm{Pd} / \mathrm{C})$ prior to the addition of sodium borohydride followed by reoxidation of the resulting hydroquinones with ferric chloride. In addition, the monofunctional 9-hydroxymethyl-substituted quinone 9 was prepared for the study of the activation of mitosenes under reductive conditions. This mitosene derivative 9 was obtained according to the literature ${ }^{17}$ from the known 2,3,5,8-tetrahydro-7-methoxy-6-methyl-5,8-dioxo-1 $H$-pyrrolo[1,2-a] indole-9-carboxaldehyde. ${ }^{15}$

The quinone diols $8 \mathrm{a}-\mathbf{d}$ are useful starting materials for further conversion into biologically active bifunctional alkylating compounds. A variety of reactions was investigated for the introduction of several substituents. The diacetates $10 \mathbf{a}-\mathbf{d}$ were prepared in good yields from $8 \mathbf{a}-\mathbf{d}$ by reaction with an excess of acetic anhydride in dichloromethane with triethylamine as a base and a catalytic amount of 4-(dimethylamino)pyridine (DMAP). In order to examine the effect of a halogen atom at C-6 in the pyrrolo[1,2-a]indole 11 and at C-3 in the pyrido[1,2-a]indole 12 on the biological activity, we brominated 10a and $10 \mathrm{c}$, respectively, in acetic acid containing sodium acetate trihydrate. ${ }^{10 \mathrm{~d}}$ The mono- $N$-ethylcarbamates $13 \mathrm{a}-\mathrm{d}$ were obtained upon treatment of the quinone diols $8 \mathbf{a}-\mathbf{d}$ with an excess of ethyl isocyanate in dichloromethane in the presence of triethylamine. The analogous reaction of similar compounds with methyl isocyanate has been described in the literature. ${ }^{10 d, 17}$ Despite of the fact that an excess of ethyl isocyanate was used, even prolonged heating yielded only the C-10 functionalized compounds $\mathbf{1 3 a}, \mathbf{b}$ and the C-11 $N$-ethylcarbamates $13 \mathrm{c}, \mathbf{d}$. Maybe after reaction of the primary, more reactive alcohol group with ethyl isocyanate, the resulting carbamate moiety sterically hinders the formation of a second carbamate at C-1 in 13a,b and $\mathrm{C}-9$ in $13 \mathrm{c}, \mathrm{d}$, respectively. In order to investigate the effect of more lipophilic esters as leaving groups at C-1 and $\mathrm{C}-10$ of $8 \mathrm{~b}$ on the biological activity, we also synthesized the dibutyrate 14. The synthesis of this diester 14 was achieved by reaction of $\mathbf{8 b}$ with butyryl chloride analogously to the preparation of the diacetates $10 a-d$ (vide supra). Although it is known from a previous study ${ }^{10 c}$ (vide supra) that two leaving groups at $\mathrm{C}-1$ and $\mathrm{C}-10$ are necessary for significant biological activity, we attempted to convert quinone diol $8 \mathrm{a}$ into the $\mathrm{C}-10$ monoacetoxylated compound with the purpose to compare the biological activity of the monoacetate with that of the diacetate. However, upon treatment of $8 \mathbf{a}$ with 1 equiv of acetic anhydride, mixtures of both the $\mathrm{C}-1$ and $\mathrm{C}-10$ monoacetates were obtained, which could not be separated. Selective saponification of the diacetate $10 \mathrm{a}$ also turned out to be impossible, giving rise to mixtures of both monoacetates. On the other hand, when the corresponding pyrido[1,2-a]indole $8 \mathbf{c}$ was used as a starting material, the C-11 monoacetate 15 could be isolated in a yield of about $50 \%$. It has been found that a mitosene, carrying both a 7 -aziridinyl substituent and two carbamoyloxy moieties at $\mathrm{C}-1$ and $\mathrm{C}-10,{ }^{10}$ showed activity against L1210 leukemia (vide supra). Therefore, we prepared the 7-(1-aziridinyl) mitosene 16 starting from the quinone diacetate $10 \mathrm{~b}$ by treatment with aziridine in methanol.

\section{Reactions of Mitosenes with Nucleophiles under Reductive Conditions}

Several compounds were included in our study of the reactions of various nucleophiles with mitosenes under

(17) Taylor, W. G.; Leadbetter, G.; Fost, D. L.; Remers, W. A. J. Med. Chem. 1977, 20, 138 . 
<smiles>COC1=C(C)C(=O)c2c(c(CO)c3n2CCC3)C1=O</smiles><smiles></smiles>

9

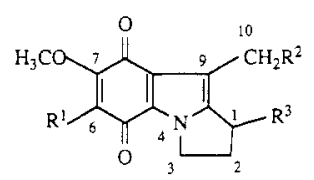

\begin{tabular}{c|ccc} 
& $\mathrm{R}^{1}$ & $\mathrm{R}^{2}$ & $\mathrm{R}^{3}$ \\
\hline $10 \mathrm{a}$ & $\mathrm{H}$ & $\mathrm{OAC}$ & $\mathrm{OAc}$ \\
$10 \mathrm{~b}$ & $\mathrm{CH}_{3}$ & $\mathrm{OAC}$ & $\mathrm{OAc}$ \\
11 & $\mathrm{Br}$ & $\mathrm{OAC}$ & $\mathrm{OAc}$ \\
$13 \mathrm{a}$ & $\mathrm{H}$ & OC(O)NHEt & $\mathrm{OH}$ \\
$13 \mathrm{~b}$ & $\mathrm{CH}_{3}$ & OC(O)NHEt & $\mathrm{OH}$ \\
14 & $\mathrm{CH}_{3}$ & OC(O)n-Pt & OC $(\mathrm{O}) \underline{\mathrm{n}}-\mathrm{PT}$
\end{tabular}

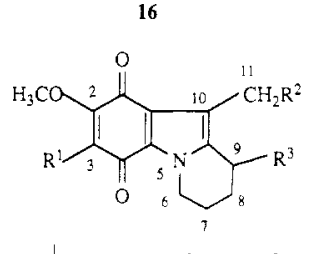

\begin{tabular}{c|ccc} 
& $\mathrm{R}^{1}$ & $\mathrm{R}^{2}$ & $\mathrm{R}^{3}$ \\
\hline $10 \mathrm{c}$ & $\mathrm{H}$ & $\mathrm{OAC}$ & $\mathrm{OAC}$ \\
$10 \mathrm{~d}$ & $\mathrm{CH}_{3}$ & $\mathrm{OAc}$ & $\mathrm{OAC}$ \\
12 & $\mathrm{Br}$ & $\mathrm{OAc}$ & $\mathrm{OAc}$ \\
$13 \mathrm{c}$ & $\mathrm{H}$ & $\mathrm{OC}(\mathrm{O}) \mathrm{NHE}$ & $\mathrm{OH}$ \\
$13 \mathrm{~d}$ & $\mathrm{CH}_{3}$ & $\mathrm{OC}(\mathrm{O}) \mathrm{NHE}$ & $\mathrm{OH}$ \\
15 & $\mathrm{H}$ & OAC & $\mathrm{OH}$
\end{tabular}

reductive conditions. In addition to the quinone diacetate $10 \mathrm{a}$ we prepared both the monoacetates 17 and 19 . The mitosene derivative 17 was prepared by acylation of the known monofunctional 9-hydroxymethyl mitosene $9 .{ }^{18}$ The isomeric monoacetate 19 was obtained in a two-step procedure from quinone aldehyde $7 \mathbf{b}$. Reduction of $\mathbf{7 b}$ using an excess of $5 \% \mathrm{Pd} / \mathrm{C}$ (vide supra) afforded a mixture of both the corresponding quinone diol $8 \mathrm{~b}$ and the overreduced compound 18 containing a methyl group at C-9 and a hydroxyl group at C-1. This hydroxy mitosene could be converted into the monoacetate 19 in the same way as 17 has been prepared.

We performed several experiments using potassium ethyl xanthate $e^{8 \mathrm{a}}$ and potassium thiobenzoate $\mathrm{e}^{7 \mathrm{a}}$ as nucleophiles. In these cases the reactions were conducted in a mixture of dichloromethane/methanol/water (1:1:1) and with sodium dithionite as a reducing agent. The reactivity of the leaving group at $\mathrm{C}-10$ under reductive conditions was investigated by adding potassium ethyl xanthate to pyrrolo[1,2-a] indole 17 followed by a solution of sodium dithionite in water. After reoxidation by air and purification by chromatography, the mitosene 20, having an ethyl xanthate substituent at C-10, could be isolated in a yield of $92 \%$. In order to investigate the difference in reactivity between the $\mathrm{C}-1$ and $\mathrm{C}-10$ leaving groups, a competition experiment was performed (Scheme II). For this purpose diacetate $10 \mathrm{a}$ was treated with potassium thiobenzoate and sodium dithionite. After oxidative workup, the only product obtained was the monothio benzoyl compound 21a, in which the C-10 acetate has been replaced by a benzoylthio moiety. Since potassium thiobenzoate is less nucleophilic than potassium ethyl xanthate ${ }^{7 \mathrm{c}}$ we also performed a reaction of $10 \mathrm{a}$ using the latter reagent under reductive conditions. In this case a similar result was obtained and only the monoethyl xanthyl mitosene $21 \mathrm{~b}$ was isolated. It should be emphasized that in all these cases the presence of sodium dithionite is a prerequisite; without this reductor no reaction takes place. These results indicate that the reductive activation of mitosenes proceeds via quinone methide and/or iminium ion intermediates. In order to obtain further evidence for the postulate that such active species are indeed the reactive intermediates, we attempted to eliminate the acetate moiety of 17 under reductive conditions. We found that when a solution of 17 in ethanol was treated with sodium borohydride ${ }^{19}$ followed by air-oxidation a fast

(18) Leadbetter, G.; Fost, D. L.; Ekwuribe, N. N.; Remers, W. A. J. Org. Chem. 1974, 39, 3580.

Scheme II<smiles>COCc1c2c(n3c1CCC3)C(=O)C(OC)=C(C)C2=O</smiles>

17<smiles>COc1cc(=O)c2c(CCO)c(COC(=O)[O-])c=2c1=O</smiles>

$10 \mathrm{a}$

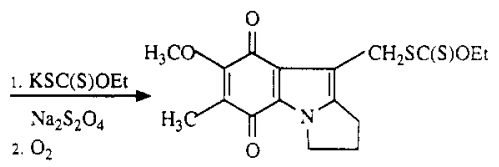

$20(92 \%)$

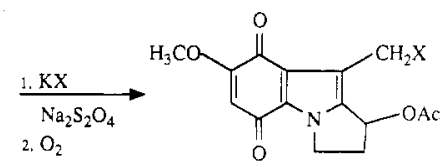

21a $X=-S C(O) P h \quad(76 \%)$ $21 \mathrm{~b} X=-\mathrm{SC}(\mathrm{S}) \mathrm{OEt}(73 \%)$<smiles>[Z]C1CCn2c3c(c(C)c21)C(=O)C(C)=C(OC)C3=O</smiles>

$10 \mathrm{~b}=\mathrm{Z}=\mathrm{OAc}$ $17 Y=O A c, Z=H$ $18 \mathrm{Y}=\mathrm{H}, \mathrm{Z}=\mathrm{OH}$ $19 \mathrm{Y}=\mathrm{H}, \mathrm{Z}=\mathrm{OAC}$

Scheme III

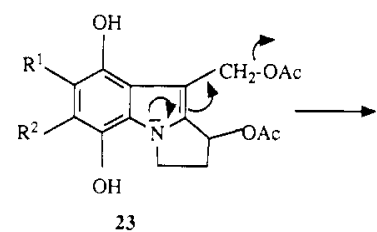<smiles>[R]c1c([R])c(O)c2c(c1O)CC(=C)C1C(OC)CCN21</smiles>

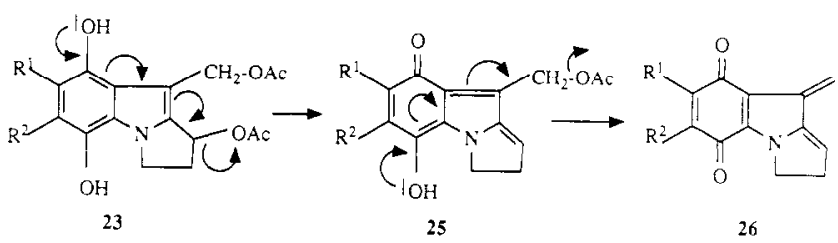

conversion into the known deacetoxylated mitosene $\mathbf{2 2}^{20}$ had taken place. In none of the preceding experiments could be observed the reductive replacement of the acetyloxy moiety at C-1. However, when we subjected a solution of 19 in ethanol to sodium borohydride and subsequently exposed the reaction mixture to oxygen, deacetoxylated mitosene 22 could be isolated. This result shows that the reductive replacement of the acetyloxy moiety at $\mathrm{C}-1$ probably also proceeds via a quinone methide and/or iminium ion intermediate. Finally, another competition experiment was performed in order to investigate the difference in reactivity between the leaving groups at $\mathrm{C}-1$ and $\mathrm{C}-10$. For this purpose $10 \mathrm{~b}$ was treated with a small excess of sodium borohydride, to afford after workup both $19(10 \%)$ and $22(30 \%)$. In addition, it was found that reaction of $10 \mathrm{~b}$ with a larger amount of sodium boro-

(19) (a) No reaction occurred when 17 was exposed to $\mathrm{Na}_{2} \mathrm{~S}_{2} \mathrm{O}_{4}$ in the presence of triethylamine. It might be that under these conditions the corresponding hydroquinone of 17 , which is produced very fast, does not eliminate the acetate moiety under formation of an iminium ion type compound similar to 24 . On the other hand, an iminium ion intermediate might be formed, but this may react again with the eliminated acetate group, instead of rearranging to 22. The tautomerization of an iminium intermediate similar to 24 has been described in ref 6a. (b) An analogous experiment on 5,6-bis[(acetyloxy)methyl]-2,3-dimethyl-1,4-benzoquinone has been described; see ref $21 \mathrm{a}$.

(20) (a) Kametani, T.; Takahashi, K.; Ihara, M.; Fukumoto, K. J Chem. Soc., Perkin Trans. 1 1979, 1847. (b) Luly, J. R.; Rapoport, H. J. Am. Chem. Soc. 1983, 105, 2859. 
hydride afforded only 22 in a yield of $40 \%$.

From these chemical experiments we may conclude that it is very likely that the biological activity of mitosenes is also based on the mechanism of bioreductive activation, ${ }^{21}$ in analogy with the reductive activation of MMC. ${ }^{4}$ In addition, the results demonstrate that reactions both at the $\mathrm{C}-1$ and $\mathrm{C}-10$ positions occur under reductive conditions, most likely via an $\mathrm{S}_{\mathrm{N}} 1$-type mechanism ${ }^{22}$ as also has been proposed in the case of MMC. .b, $, 7,8$ Finally, we have observed that when both leaving groups at C-1 and C-10 are the same the nucleophile preferably adds to $\mathrm{C}-10$ under reductive conditions. This is clearly shown by the outcome of the competition experiments with $10 \mathrm{a}$ as a starting material, i.e. the $\mathrm{C}-1$ acetyloxy moiety is not replaced and only $21 \mathrm{a}, \mathrm{b}$ are formed. The reaction of $10 \mathrm{~b}$ with sodium borohydride preferably yields products in which the $\mathrm{C}-10$ acetyloxy moiety is replaced, i.e. 19 and/or 22 (vide supra). These results indicate that the iminium ion intermediate 24 is preferred over the quinone methide intermediates 25 and 26 (Scheme III). ${ }^{23}$ Since the elimination of the C-10 leaving group yields the less substituted olefin, the reductive activation process is most likely governed by kinetic control. The predominance of the substitution site $\mathrm{C}-10$ over $\mathrm{C}-1$ is in sharp contrast with the difference in reactivity between the $\mathrm{C}-1$ and $\mathrm{C}-10$ positions in $\mathrm{MMC}$, where $\mathrm{C}-1$ is the preferred position of alkylation under reductive conditions due to the more reactive aziridine substituent. ${ }^{4 b, c, 7,8}$ For instance, when MMC was reacted with potassium thiobenzoate under reductive conditions, the ratio of $\mathrm{C}-1$ monosubstituted adducts vs $\mathrm{C}-1,10$ disubstituted adducts obtained was larger than 10:1. ${ }^{7 \mathrm{a}, \mathrm{b}}$

\section{Biological Activity}

Initially all mitosenes were studied in vitro for their biological activities against L1210 lymphocytic leukemia, ${ }^{10 a, c, d, 24} \mathrm{WiDr}$ colon carcinoma, ${ }^{25}$ and A204 rhabdomyosarcoma. ${ }^{26}$ In the L1210 tumor system the inhibition of colony formation was determined, while inhibition of cell growth in both other assays was measured by using the PIT method. ${ }^{27}$ In all three tumor systems MMC was used as a positive reference compound.

Tentative conclusions from the data in Table I are that two leaving groups are necessary for optimal activity and that mitosenes of the pyrido[1,2-a]indole type $(10, n=2)$ exhibit lower activity than the corresponding analogues in the pyrrolo[1,2-a]indole $(n=1)$ series. It is difficult to explain the differences in biological activity between the five- and six-membered mitosenes. The lower activities of the pyrido[1,2-a]indole derivatives may be ascribed to

(21) (a) Lin, A. J.; Sartorelli, A. C. J. Org. Chem. 1973, 38, 813. (b) Moore, H. W.; Czerniak, R. Med. Res. Rev. 1981, 1, 249.

(22) No reaction occurred when compound $4 \mathrm{~b}$ was treated with $\mathrm{NaBH}_{4}$ in $\mathrm{EtOH}$. Therefore, the removal of the acetyloxy moiety at $\mathrm{C}-1$ in the corresponding mitosene $10 \mathrm{~b}$ or 19 most likely occurs via a $S_{\mathrm{N}} 1$-type mechanism.

(23) It should be noted that the compounds/intermediates in Scheme III are drawn as hydroquinones for convenience. Maybe the intermediates are semiquinone radical anions ${ }^{6}$ rather than hydroquinones, but the present findings have no bearing on this matter.

(24) It should be noted that the L1210 tumor system is not very sensitive to mitosenes as has been reported.10b However, several mitosenes showed activities in this particular assay. ${ }^{10 a, c}$

(25) Noguchi, P.; Wallace, R.; Johnson, J.; Earley, E. M.; O'Brien, S.; Ferrone, S.; Pellegrino, M. A.; Milstien, J.; Needy, C.; Browne, W.; Petricciani, J. In Vitro 1979, 15, 401.

(26) Giard, D. J.; Aaronson, S. A.; Todaro, G. J.; Arnstein, P.; Kersey, J. H.; Dosik, H.; Parks, W. P. J. Natl. Cancer Inst. $1973,51,1417$.

(27) van Lambalgen, R.; Lelieveld, P. Invest. New Drugs 1987, 5, 161.
Table I. In Vitro Activity of Mitosenes against A204, WiDr, L1210

\begin{tabular}{crrr}
\hline & \multicolumn{3}{c}{$\mathrm{ID}_{50}{ }^{a} \mathrm{ng} / \mathrm{mL}$} \\
\cline { 2 - 4 } compound & ${\mathrm{A} 204^{b}}^{b}$ & $\mathrm{WiDr}^{b}$ & $\mathrm{~L} 1210^{c}$ \\
\hline $\mathbf{8 a}$ & 2599 & 2599 & 1146 \\
$\mathbf{8 b}$ & 641 & 1333 & 2605 \\
$\mathbf{8 c}$ & 1196 & 2171 & 1326 \\
$\mathbf{8 d}$ & 2690 & 5889 & 3723 \\
$\mathbf{1 0 a}$ & 8 & 37 & 495 \\
$\mathbf{1 0 b}$ & 1 & 10 & 140 \\
$\mathbf{1 0 c}$ & 133 & $\mathbf{1 1 5}$ & 582 \\
$\mathbf{1 0 d}$ & $<100$ & 171 & 1538 \\
$\mathbf{1 1}$ & 479 & 492 & 217 \\
$\mathbf{1 2}$ & 4136 & 6489 & 1118 \\
$\mathbf{1 3 a}$ & 1 & 29 & 118 \\
$\mathbf{1 3 b}$ & 1 & 51 & 206 \\
$\mathbf{1 3 c}$ & $<100$ & 180 & 942 \\
$\mathbf{1 3 d}$ & 50 & 251 & 1167 \\
$\mathbf{1 4}$ & 21 & 69 & $>640$ \\
$\mathbf{1 5}$ & 115 & 287 & 1753 \\
$\mathbf{1 6}$ & 1 & 20 & 166 \\
$\mathbf{2 0}$ & 585 & 3705 & $>6400$ \\
MMC & 20 & 31 & 31 \\
\hline
\end{tabular}

anhibition of colony formation (L1210) or cell growth (WiDr and A204) after in vitro treatment with mitosenes. MMC was used as a positive reference compound. ${ }^{b}$ For a detailed description of the PIT method, see ref 27 . ' For a detailed description of the L1210 assay, see ref 38 .

unfavorable steric or other factors imposed on these compounds by the additional $\mathrm{CH}_{2}$ moiety. ${ }^{28}$ For further studies we selected the mitosene bisacetates $10 \mathrm{a}$ and $10 \mathrm{~b}$ on the basis of the promising in vitro activities against all three tumor model systems (see Table I). Furthermore, MMC was used as a positive reference compound and we also selected mitosene diol $\mathbf{8 b}$, which lacks both good leaving acetate groups at $\mathrm{C}-1$ and $\mathrm{C}-10$. The purpose of this second study with the selected mitosenes was to investigate (i) general drug activity and (ii) selective drug activity under hypoxic conditions. Several tumor models were used, viz. P388 leukemia in CD2 mice as a highly sensitive model, ${ }^{10 a, c}$ human tumors maintained as xenografts in nude mice, ${ }^{29}$ and two types of solid mouse adenocarcinomas of the colon (MAC $13^{30 a, b}$ and MAC $16^{30 c, d}$ ). The in vivo activities against P388 leukemia of the drugs are given in Table II. The mitosenes and MMC were administered either as a single intraperitoneal (ip) injection or daily (ip) during 9 consecutive days. These experiments led to the following conclusions for this test system. Firstly, the mitosene diol $\mathbf{8 b}$ and the 6-unsubstituted mitosene diacetate 10a are inactive. Secondly, the 6methyl mitosene diacetate $10 \mathrm{~b}$ is marginally active after single-dose administration and moderately active after fractioned dosage. Thirdly, all mitosenes tested are inferior to MMC. As a second model system, human tumor xenografts were used in an in vitro clonogenic assay (Table III).

(28) It might be possible that the pyrido[1,2-a]indole type derivatives have unfavorable lipophilicity. This variable was not determined, because the results of several studies of Remers et al. ${ }^{10 a, d}$ have revealed that no statistically significant correlation exists between antitumor potency of the mitosenes investigated and their lipophilicity.

(29) Fiebig, H. H.; Schmid, J. R.; Bieser, W.; Henss, H.; Lohr, G. W. Eur. J. Cancer Clin. Oncol. 1987, 23, 937.

(30) (a) Double, J. A.; Ball, C. R. Cancer Chemother. Rep., Part I 1975, 59, 1083. (b) Double, J. A.; Bibby, M. C.; McCormick, J. E.; McElhinney, R. S. Anti-Cancer Drug Des. 1986, 1, 133. (c) Bibby, M. C.; Double, J. A.; Ali, S. A.; Fearon, K. C. H.; Brennan, R. A.; Tisdale, M. J. J. Natl. Cancer Inst. 1987, 78, 539. (d) Bibby, M. C.; Double, J. A.; Loadman, P. M. Br. J. Cancer 1988, 58, 341. 
Table II. Activity of Mitosenes $8 \mathbf{b}, 10 a, 10 b$, and MMC against P388 Leukemia in CD2 Mice

\begin{tabular}{|c|c|c|c|c|c|c|c|c|}
\hline \multirow[b]{2}{*}{ compound } & \multicolumn{4}{|c|}{ single dose treatment } & \multicolumn{4}{|c|}{ fractioned dose treatment ${ }^{a}$} \\
\hline & $\begin{array}{l}\text { dose, } \\
\mathrm{mg} / \mathrm{kg}\end{array}$ & $\begin{array}{c}\% \\
\mathrm{BWC}^{b}\end{array}$ & $\begin{array}{l}\text { MST, }^{c} \\
\text { days }\end{array}$ & $\begin{array}{c}\% \\
\mathrm{~T} / \mathrm{C}^{d}\end{array}$ & $\begin{array}{l}\text { dose, } \\
\mathrm{mg} / \mathrm{kg}\end{array}$ & $\begin{array}{c}\% \\
\mathrm{BWC}^{b}\end{array}$ & $\begin{array}{c}\text { MST, } \\
\text { days }\end{array}$ & $\begin{array}{c}\% \\
\mathrm{~T} / \mathrm{C}^{d}\end{array}$ \\
\hline \multirow[t]{2}{*}{$8 \mathbf{b}$} & 50 & +2.5 & 11 & 100 & 18 & +17.3 & 11 & 100 \\
\hline & 70 & -0.9 & 10 & 91 & 25 & +17.1 & 11 & 100 \\
\hline \multirow[t]{2}{*}{$10 \mathrm{a}$} & 8 & -2.0 & 11 & 100 & 2 & -20.9 & 12 & 109 \\
\hline & 12 & -1.8 & 10 & 91 & & & & \\
\hline \multirow[t]{2}{*}{$10 \mathrm{~b}$} & 6 & -4.7 & 13 & 118 & 1.5 & +8.3 & 15.5 & 141 \\
\hline & 8 & -7.1 & 9 & 82 & 2.5 & +2.0 & 16.5 & 150 \\
\hline \multirow[t]{2}{*}{ MMC } & 6 & -18.1 & 21 & $191^{e}$ & 1 & -5.4 & 34 & $309^{f}$ \\
\hline & 3 & -8.0 & 21 & 191 & & & & \\
\hline
\end{tabular}

${ }^{a}$ Drug given during 9 consecutive days. ${ }^{b} \mathrm{BWC}=$ body weight change (day $6-$ day 1 ) $/$ day $1 .{ }^{c} \mathrm{MST}=$ median survival time. ${ }^{d} \% \mathrm{~T} / \mathrm{C}$ : significant effect $=120$. ${ }^{e} \mathrm{MMC}$ had one long term survivor (60 days) out of five. ${ }^{f} \mathrm{MMC}$ had two long term survivors (60 days) out of five.

Table III. In Vitro Effect of MMC and the Mitosenes $8 \mathbf{b}, 10 a$, and 10 in Human Tumor Xenografts ${ }^{a}$

\begin{tabular}{ccccc}
\hline & \multicolumn{4}{c}{ active/total at } \\
& \multicolumn{4}{c}{ drug concentration $(\mu \mathrm{g} / \mathrm{mL})$} \\
\cline { 2 - 5 } compound & 0.01 & 0.05 & 0.1 & 1 \\
\hline $\mathbf{8 b}$ & $0 / 3$ & & $1 / 3$ & $1 / 3$ \\
$10 \mathbf{a}$ & $0 / 7$ & & $3 / 7$ & $5 / 7$ \\
$10 \mathrm{~b}$ & $5 / 22$ & & $13 / 21$ & $18 / 20$ \\
MMC & & $42 / 104$ & & \\
\hline
\end{tabular}

aAll human tumors were maintained as xenografts in nude mice. They include: colon, gastric, lung (adeno-, large cell, epidermoid cell, small cell), mammary, melanoma, pleuramesothelioma, sarcoma, testicular, and miscellaneous cancer xenografts. For a detailed description of the assays, see ref 29 . Activity is defined as an inhibition of tumor colony growth greater than $70 \%$.

The lung xenograft LXFG 529 and the gastric xenograft GXF 97 were most sensitive to all mitosenes and MMC. Consequently, these tumors were also tested for their sensitivity in vivo. In contrast to MMC, which was active in lung xenograft LXFG 529, none of the mitosenes caused any delay in the tumor growth progression of this particular xenograft, even when toxic doses were applied. However, both 6 -methyl mitosene diacetate $10 \mathrm{~b}$ and $\mathrm{mi}$ tosene diol $\mathbf{8 b}$ were active against the gastric xenograft GXF 97, while mitosene diacetate 10a was not active at all in this tumor model (Table IV).

The mitosenes $8 \mathrm{~b}$ and $10 \mathrm{~b}$ were administered daily (ip) during 4 consecutive days, while MMC was given as a single intravenous injection. Both $\mathrm{MMC}$ and mitosenes $8 \mathrm{~b}$ and $10 \mathrm{~b}$ gave a partial remission of the tumor. Mitosene diol $8 \mathbf{b}$ is only active at high doses $(25-50 \mathrm{mg} / \mathrm{kg})$ and therefore less potent than MMC, while mitosene bisacetate 10b is about as equal in potency as MMC although it was administered by fractioned dosage $(3-6 \mathrm{mg} / \mathrm{kg}$ ). Both mitosenes $8 \mathrm{~b}$ and $\mathbf{1 0 b}$ were equally effective in prolonging life span as MMC. We have no explanation why the 6 -unsubstituted mitosene $10 \mathrm{a}$ is inactive in this tumor model.

As a next model system the tumor line MAC $13^{30 \mathrm{a}, \mathrm{b}}$ was tested for sensitivity either 2 (early) or 29 (late) days after grafting. This tumor model was chosen, because MMC and mitosenes can be (bio)reductively activated (vide supra). Since the drugs will probably exert low activity when tested under euoxic conditions, we reasoned that a solid tumor with an anoxic fraction might be a better model. Histopathology of the late tumors showed only a small degree of necrosis (ca. 10\%), suggesting hypoxia/anoxia, and this may be responsible for the marginal improvement in the activity of MMC in the "late" tumors. However, with hindsight it is thought that this model shows an insufficient differential in hypoxia to demonstrate (bio)reduction and inactivity may not be that meaningful; therefore mitosenes 10a and 10b were not tested in the "late" tumor system (Table V). Perhaps the mitosenes will reveal more activity on different tumor lines with a much higher hypoxic cell fraction. Since the MAC 16 solid tumor is potentially useful in this context, ${ }^{30 c, d}$ we decided to investigate the antitumor activity of $\mathrm{MMC}$ and the mitosenes $8 \mathbf{b}, \mathbf{1 0 a}$, and $10 \mathrm{~b}$ against this model system (Table V). MAC 16 is a moderately well differentiated adenocarcinoma of the colon that produces necrotic regions and induces a considerable weight loss in mice. It is passaged by subcutaneous implant into the flank of female NMRI mice. The tumor volumes were determined by known procedures, ${ }^{30 c, d}$ and the mean relative body weight of the mice was also obtained twice weekly. The study was terminated when the tumors in the untreated control group became unacceptably large (day 12). MMC was moderately active in the MAC 16 system, while mitosene diol $\mathbf{8 b}$ produced a small beneficial effect.

The rather disappointing in vivo results raise several important points. It is quite clear in screening for bioreductive compounds that there is a need for tumor models with a high degree of hypoxia/anoxia. However, tumors with poor vascular supply and necrosis may pose problems of bioavailability and this will also apply to the clinical situation. In this respect the results with MMC on MAC 16 are encouraging and even the small effect of $8 b$ could be regarded as positive as the tumor is refractory to conventional alkylating agents. ${ }^{30 \mathrm{~d}}$

Table IV. In Vivo Antitumor Effect of Mitosenes 8b, 10a, 10b, and MMC on Human Tumor Xenograft GXF 97 at Optimal Dose ${ }^{a}$

\begin{tabular}{|c|c|c|c|c|c|c|c|c|c|}
\hline \multirow[b]{2}{*}{ compound } & \multirow{2}{*}{$\begin{array}{c}\text { dose, } \\
\text { mg/kg } \\
\text { per day }\end{array}$} & \multirow{2}{*}{$\begin{array}{c}\text { schedule, } \\
\text { days }\end{array}$} & \multicolumn{3}{|c|}{$\% \mathrm{~T} / \mathrm{C}^{b}$} & \multirow{2}{*}{$\begin{array}{c}\text { rTS, } \%: \\
\text { day } 28\end{array}$} & \multicolumn{3}{|c|}{$\% \mathrm{BWC}^{d}$} \\
\hline & & & day 14 & day 21 & day 28 & & day 14 & day 21 & day 28 \\
\hline $8 b$ & 50 & $1-4$ & 12.6 & 4.8 & 3.1 & 20.6 & 103.8 & 107.2 & 103.4 \\
\hline $10 \mathrm{a}$ & $3^{e}$ & $1-4$ & 39.3 & 31.7 & 31.7 & 210.1 & 89.6 & 86.5 & 87.1 \\
\hline $10 \mathrm{~b}$ & 6 & $1-4$ & 16.8 & 5.9 & 3.9 & 26.2 & 71.0 & 73.5 & 74.1 \\
\hline MMC & 2 & 1 & 9.9 & 4.1 & 2.6 & 17.0 & 108.9 & 108.5 & 108.4 \\
\hline
\end{tabular}

\footnotetext{
${ }^{a}$ For a detailed description of the experiments, see ref 29 . Four to five mice were used in each experiment. The human tumor xenograft was grown subcutaneously in nude mice for 24 days, whereupon the mice were randomized. Treatment was started 1 day later. The mitosenes were given fractioned as ip injections, while $\mathrm{MMC}$ was administered as a single iv injection. ${ }^{b} \mathrm{~T} / \mathrm{C}=$ median relative tumor size of treated /median relative tumor size of controls. The tumor size was determined by measuring length and width. ${ }^{c} \mathrm{rTS}=$ relative tumor size, \% rTS of the controls at day 28 was determined: 662.5 . Complete remission, rTS $\leq 10 \%$; partial remission, $10 \%<\mathrm{rTS} \leq 50 \%$; minor remission, $50 \%<\mathrm{rTS} \leq 75 \%$; no change, $75 \%<\mathrm{rTS} \leq 125 \%$; progression, $125 \%<\mathrm{rTS}$. ${ }^{d} \mathrm{BWC}=$ mean relative body weight change of treated/mean relative body weight change of controls. ${ }^{e}$ At higher doses bone marrow toxicity was observed.
} 
Table V. In Vivo Antitumor Effect of MMC and the Mitosenes $\mathbf{8 b}, \mathbf{1 0 a}$, and $10 \mathbf{b}$ on MAC $13^{a}$ and MAC $16^{b}$ at Optimal Dose

\begin{tabular}{|c|c|c|c|c|c|c|c|c|c|c|}
\hline \multirow[b]{3}{*}{ compound } & \multirow{3}{*}{$\begin{array}{c}\text { dose, } \\
\mathrm{mg} / \mathrm{kg}\end{array}$} & \multicolumn{4}{|c|}{ MAC 13} & \multirow{3}{*}{$\begin{array}{l}\text { dose, } \\
\mathrm{mg} / \mathrm{kg}\end{array}$} & \multicolumn{4}{|c|}{ MAC 16} \\
\hline & & \multicolumn{2}{|c|}{ day 2} & \multicolumn{2}{|c|}{ day 29} & & \multicolumn{2}{|c|}{ day 4} & \multicolumn{2}{|c|}{ day 12} \\
\hline & & $\% \mathrm{~T} / \mathrm{C}^{c}$ & $\% \mathrm{I}^{d}$ & $\% \mathrm{~T} / \mathrm{C}^{c}$ & $\overline{\% \mathrm{I}^{d}}$ & & $\% \mathrm{~T} / \mathrm{C}^{\mathrm{c}}$ & $\% \mathrm{BW}^{\mathrm{B}}$ & $\% \mathrm{~T} / \mathrm{C}^{c}$ & $\% \mathrm{BW}$ \\
\hline $8 b$ & 50 & 97 & 3 & 121 & -21 & 40 & $102^{f}$ & $118^{\prime}$ & 89 & 93 \\
\hline $10 \mathrm{a}$ & 10 & 152 & -52 & $e$ & $e$ & 10 & 99 & 105 & 104 & 81 \\
\hline $10 \mathrm{~b}$ & 10 & 73 & 27 & $e$ & $e$ & 12.5 & 102 & 105 & 120 & 78 \\
\hline MMC & 6 & 11.6 & 88.4 & 7.4 & 92.6 & 6 & 60 & 106 & 81 & 96 \\
\hline
\end{tabular}

${ }^{a}$ For a detailed description of the experiments, see ref $30 \mathrm{a}, \mathrm{b}$. Five to ten female NMRI mice were used for each experiment. Fifteen days after treatment the mice were killed and weighed, the tumor was carefully excised, and the carcass without tumor was reweighed. The tumor weight was determined by the difference, because weighing of the excised tumor was impractical due to the high fluid content of MAC 13 . The drugs were administered in arachis oil BP by ip route on day 2 or day $29 .{ }^{b}$ For a detailed description of the experiments, see ref $30 \mathrm{c}$. ${ }^{c}$ Five female NMRI mice were used for each experiment. Treatment started at a time when the tumors were accurately measurable (day 0 ) by administration of the drugs in arachis oil BP ip. The tumor size was measured by caliper at day 0 and twice weekly thereafter (see ref $30 \mathrm{c}, \mathrm{d})$. Tumor volume was normalized with respect to the initial volume and the mean volume for each group calculated for each point of time. The study was terminated when the tumors in the untreated control group became unacceptably large. The mean relative body weight of the mice was also obtained twice weekly. (c) $\mathrm{T} / \mathrm{C}=$ tumor weight (volume) treated/tumor weight (volume) untreated controls. ${ }^{d} \mathrm{I}$ $=$ inhibition, $-\mathrm{I} \%$ indicates stimulation. ${ }^{e}$ Not determined. $/$ Values determined by extrapolation; tumor volume and body weight actually determined at day $3,{ }^{8} \mathrm{BW}=$ body weight treated/body weight untreated controls.

\section{Conclusion}

The results of the biological activity of mitosenes in our work and that of Remers et al. ${ }^{10 a, c, d}$ show that some of these compounds give a prolongation of hife span comparable to that of MMC, but at higher optimal doses. Remers et al. ${ }^{10 \mathrm{c}}$ have stated that a leaving group at C-1 appears to be necessary for significant antitumor activity. The present study supports the findings of Remers et al. ${ }^{10 a, c, d}$ that for a bioreductive activation an optimally functionalized mitosene derivative should have two leaving groups, both at $\mathrm{C}-1$ and $\mathrm{C}-10$, and a methyl group at C-6. Furthermore, the fact that the leaving group at $\mathrm{C}-10$ is easier replaced than that at C-1, when both are equal (vide supra), apparently deserves more attention. This finding may contribute to a better design of mitosenes, because until now a limited number of C-10 substituents (usually esters and carbamates) have been subject of investigations.

As can be seen in the Tables $\mathrm{I}-\mathrm{V}$ the in vitro activities of the selected mitosenes $10 \mathrm{a}$ and $10 \mathrm{~b}$, containing two good leaving groups, are high. However, their activities in vivo are not so high in most cases. Probably we are dealing with a problem of pharmacokinetic nature, i.e. the mitosenes are subject to some kind of metabolism process before reaching the tumor tissue. In contrast to most of the in vivo results are the findings that both mitosene diacetate $10 \mathrm{~b}$ and mitosene diol $8 \mathrm{~b}$ are very active against the gastric xenograft GXF 97. In this context it should be stated that MMC is an effective treatment for gastric tumors, ${ }^{31}$ and this is confirmed by the high activity of MMC against GXF 97 (Table IV). It is conceivable that the bioreductive activation process is not or not the only process that is operative in GXF 97. In this gastric xenograft it is possible that the acidic activation process ${ }^{5}$ is of importance, possibly because of the lower $\mathrm{pH}$ found in gastric tumor cells. ${ }^{31}$ The reasons why mitosene diol $\mathbf{8 b}$, which lacks both leaving groups at C-1 and C-10, is active (although at high doses) in this particular model system are not clear. It is possible that both hydroxyl groups are converted into better leaving groups by phosphorylation or may be acetylation, or that they are protonated at lower $\mathrm{pH}$ and subsequently replaced, but we have no evidence for such processes.

In contrast to Remers et al. ${ }^{10 a, c d}$ we believe that the results of the investigations concerning the biological activities of some mitosenes encourage further research in this field. Especially, the biological evaluation of mitosene diol $\mathbf{8 b}$ deserves more attention.

(31) Douglass, H. O.; Lavin, P. T.; Goudsmit, A.; Klassen, D. J.; Paul, A. R. J. Clin. Oncol. 1984, 2, 1372.

\section{Experimental Section}

Melting points were determined with a Reichert melting point apparatus and are uncorrected. ${ }^{1} \mathrm{H}$ NMR spectra $\left(\mathrm{CDCl}_{3}\right)$ were recorded with a Bruker WP- 80 spectrometer and ${ }^{13} \mathrm{C}$ NMR spectra $\left(\mathrm{CDCl}_{3}\right)$ were recorded with a Nicolet NT-200 WB spectrometer $\left(\mathrm{Me}_{4} \mathrm{Si}\right.$ as an internal standard). Mass spectra were recorded with a Varian MAT $311 \mathrm{~A}$ spectrometer and IR spectra with a Perkin-Elmer 257 spectrophotometer. Elemental analyses were carried out by A. Montanaro-Christenhusz of the Laboratory of Chemical Analysis of the University of Twente.

Solvents were distilled prior to use as follows: $\mathrm{CH}_{3} \mathrm{CN}, \mathrm{CH}_{2} \mathrm{Cl}_{2}$, $\mathrm{CHCl}_{3}$, benzene, and toluene from $\mathrm{P}_{2} \mathrm{O}_{5}$ and THF from sodium/benzophenone ketyl. Column chromatography was performed with silica gel, unless otherwise stated. All reactions were carried out under a nitrogen atmosphere. Pe. is the abbreviation of petroleum ether (bp 60-80 ${ }^{\circ} \mathrm{C}$ ).

General Procedure for the Synthesis of the Acetyloxylated 2,3-Dihydro- $1 H$-pyrrolo- and 6,7,8,9-Tetrahydropyrido[1,2-a ]indoles 4 . A solution of the nitriles $3 \mathrm{a}-\mathrm{d}^{12 \mathrm{~b}}(21.9$ $\mathrm{mmol})$ and lead tetraacetate $(13.3 \mathrm{~g}, 30.0 \mathrm{mmol})$ in acetic acid $(375 \mathrm{~mL})$ was stirred at room temperature until the reaction was complete (about 3-7 days for $\mathbf{4 b - d}$ and 3.5 weeks $^{32}$ for $\mathbf{4 a}$ ) as followed from TLC $\left(\mathrm{CHCl}_{3} / \mathrm{EtOAc}=9: 1\right)$. After removal of the solvent under reduced pressure at temperatures $<40^{\circ} \mathrm{C}$, the residue was partitioned between water $(200 \mathrm{~mL})$ and $\mathrm{CHCl}_{3}(200$ $\mathrm{mL})$. The layers were separated, the water layer was extracted with $\mathrm{CHCl}_{3}(2 \times 200 \mathrm{~mL})$, and the combined organic layers were filtered over Hyflo. After washing with a $\mathrm{NaHCO}_{3}$ solution (200 $\mathrm{mL}$ ) and drying over $\mathrm{MgSO}_{4}$, the solvent was removed in vacuo. The compounds were purified by chromatography: 4a,c with $\mathrm{CHCl}_{3} /$ EtOAc $=95: 5$ as eluent and $4 \mathbf{b}, \mathbf{d}$ with $\mathrm{CHCl}_{3} / \mathrm{EtOAc}=$ 9:1 as eluent. Compound $4 \mathrm{~b}$ was isolated as a solid in a yield of 47\%: $\mathrm{mp} 146-147^{\circ} \mathrm{C}\left(\mathrm{Et}_{2} \mathrm{O}\right)$ (lit. ${ }^{13} \mathrm{mp} 133-134^{\circ} \mathrm{C}$ ).

1-(Acetyloxy)-2,3-dihydro-7-methoxy- $1 H$-pyrrolo[1,2-a ]indole-9-carbonitrile (4a): yield $64 \% ; \mathrm{mp} 114-115^{\circ} \mathrm{C}(\mathrm{EtOH})$; ${ }^{1} \mathrm{H}$ NMR $\delta 7.23(\mathrm{~d}, 1 \mathrm{H}, J=8.8 \mathrm{~Hz}, \mathrm{H}-5), 7.15(\mathrm{~d}, 1 \mathrm{H}, J=2.4$ $\mathrm{Hz}, \mathrm{H}-8$ ), 6.93 (dd, $1 \mathrm{H}, J=2.4$ and $8.8 \mathrm{~Hz}, \mathrm{H}-6$ ), 6.31 (dd, $1 \mathrm{H}$, $J=3.2$ and $7.1 \mathrm{~Hz}, \mathrm{CHOAc}), 3.86\left(\mathrm{~s}, 3 \mathrm{H}, \mathrm{OCH}_{3}\right), 2.13(\mathrm{~s}, 3 \mathrm{H}$, $\left.\mathrm{CH}_{3}\right) ;{ }^{13} \mathrm{C}$ NMR $\delta 170.0(\mathrm{~s}, \mathrm{C}=0), 156.1$ (s, C-7), $114.8(\mathrm{~d}, \mathrm{C}-6)$, 111.8 (d, C-5), 101.3 (d, C-8), 79.5 (s, C-9), 68.9 (d, CHOAc), 55.7 $\left(\mathrm{q}, \mathrm{OCH}_{3}\right), 43.7\left(\mathrm{t}, \mathrm{NCH}_{2}\right), 20.7\left(\mathrm{q}, \mathrm{CH}_{3}\right) ; \mathrm{IR}(\mathrm{KBr}) 2220(\mathrm{CN})$, $1730(\mathrm{C}=\mathrm{O}) \mathrm{cm}^{-1} ; \mathrm{MS}, \mathrm{m} / \mathrm{z}\left(\mathrm{M}^{+}\right)$calcd 270.100 , found 270.099 . Anal. $\left(\mathrm{C}_{15} \mathrm{H}_{14} \mathrm{~N}_{2} \mathrm{O}_{3}\right) \mathrm{C}, \mathrm{H}, \mathrm{N}$.

9-(Acetyloxy)-6,7,8,9-tetrahydro-2-methoxypyrido[1,2-a ]indole-10-carbonitrile (4c): yield $83 \% ; \mathrm{mp} 137-138^{\circ} \mathrm{C}(\mathrm{EtOH})$; ${ }^{1} \mathrm{H}$ NMR $\delta 7.35-7.1(\mathrm{~m}, 2 \mathrm{H}, \mathrm{H}-1$ and $\mathrm{H}-4), 6.93(\mathrm{dd}, 1 \mathrm{H}, J=$ 2.4 and $9.7 \mathrm{~Hz}, \mathrm{H}-3), 6.45-6.15(\mathrm{~m}, 1 \mathrm{H}, \mathrm{CHOAc}), 3.86(\mathrm{~s}, 3 \mathrm{H}$, $\left.\mathrm{OCH}_{3}\right), 2.19\left(\mathrm{~s}, 3 \mathrm{H}, \mathrm{CH}_{3}\right) ;{ }^{13} \mathrm{C} \mathrm{NMR} \delta 170.0(\mathrm{~s}, \mathrm{C}=\mathrm{O}), 156.2(\mathrm{~s}$, C-2), 114.5 (d, C-3), 111.0 (d, C-4), 100.5 (d, C-1), 83.8 (s, C-10), 64.1 (d, $\mathrm{CHOAc}$ ), 55.7 (q, $\left.\mathrm{OCH}_{3}\right), 42.4$ (t, $\mathrm{NCH}_{2}$ ), 20.7 (q, $\mathrm{CH}_{3}$ ); IR (KBr) $2210(\mathrm{CN}), 1730(\mathrm{C}=\mathrm{O}) \mathrm{cm}^{-1} ; \mathrm{MS}, \mathrm{m} / z\left(\mathrm{M}^{+}\right)$calcd

(32) Kametani et al. ${ }^{13}$ reported that the acetoxylation of $\mathbf{3 a}$ took place within several hours. 
284.116, found 284.117. Anal. $\left(\mathrm{C}_{16} \mathrm{H}_{16} \mathrm{~N}_{2} \mathrm{O}_{3}\right) \mathrm{C}, \mathrm{H}, \mathrm{N}$.

9-(Acetyloxy)-6,7,8,9-tetrahydro-2-methoxy-3-methylpyrido[1,2-a ]indole-10-carbonitrile (4d): yield $84 \% ; \mathrm{mp}$ $107-108{ }^{\circ} \mathrm{C}(\mathrm{EtOH}) ;{ }^{1} \mathrm{H}$ NMR $\delta 7.10(\mathrm{~s}, 1 \mathrm{H}, \mathrm{H}-4), 7.04(\mathrm{~s}, 1 \mathrm{H}$, $\mathrm{H}-1), 6.35-6.15(\mathrm{~m}, 1 \mathrm{H}, \mathrm{CHOAc}), 3.88\left(\mathrm{~s}, 3 \mathrm{H}, \mathrm{OCH}_{3}\right), 2.33(\mathrm{br}$ $\left.\mathrm{s}, 3 \mathrm{H}, \mathrm{CH}_{3}\right) ;{ }^{13} \mathrm{C}$ NMR $\delta 170.0(\mathrm{~s}, \mathrm{C}=0), 154.9(\mathrm{~s}, \mathrm{C}-2), 111.4(\mathrm{~d}$, C-4), 98.9 (d, C-1), 83.3 (s, C-10), 64.2 (d, CHOAc), 55.7 (q, $\mathrm{OCH}_{3}$ ), $42.3\left(\mathrm{t}, \mathrm{NCH}_{2}\right.$ ), 20.7 (q, $\mathrm{CH}_{3}$ ), 17.3 (q, $\mathrm{ArCH}_{3}$ ); IR (KBr) $2220(\mathrm{CN})$, $1730(\mathrm{C}=\mathrm{O}) \mathrm{cm}^{-1} ; \mathrm{MS}, \mathrm{m} / z\left(\mathrm{M}^{+}\right)$calcd 298.132 , found 298.132 . Anal. $\left(\mathrm{C}_{17} \mathrm{H}_{18} \mathrm{~N}_{2} \mathrm{O}_{3}\right) \mathrm{C}, \mathrm{H}, \mathrm{N}$.

General Procedure for the Synthesis of the Pyrrolo- and Pyrido[1,2-a ]indolecarboxaldehydes 5. To a solution of $\mathrm{NaOMe}(65.2 \mathrm{mmol}$, prepared from $1.5 \mathrm{~g}$ of sodium) in dry methanol $(115 \mathrm{~mL})$ was added dropwise a solution of $4 \mathbf{a}-\mathbf{d}$ (19 $\mathrm{mmol}$ ) in methanol $(500 \mathrm{~mL})$. After stirring for $15 \mathrm{~min}$ the solvent was evaporated and the residue taken up in $\mathrm{CHCl}_{3}(300 \mathrm{~mL})$ and washed with a $\mathrm{NH}_{4} \mathrm{Cl}$ solution $(300 \mathrm{~mL})$ and brine $(300 \mathrm{~mL})$. After drying with $\mathrm{MgSO}_{4}$ and removal of the solvent in vacuo, the crude alcohols were obtained, which were used without purification.

A mixture of the alcohol $(4.6 \mathrm{mmol})$ and nickel aluminum alloy $(2.0 \mathrm{~g})$ in $50 \%$ aqueous acetic acid $(150 \mathrm{~mL})$ was placed in a conical flask and immersed in an oil bath with a temperature of $140^{\circ} \mathrm{C}$. Stirring at this temperature was continued for $1-2.5 \mathrm{~h}$ until no more starting material could be detected by TLC (EtOAc). Water $(200 \mathrm{~mL})$ was added, the reaction mixture was filtered over Hyflo, and the resulting solution was extracted with $\mathrm{CHCl}_{3}(3 \times 100 \mathrm{~mL})$. The combined extracts were washed with a $\mathrm{NaHCO}_{3}$ solution (4 $\times 100 \mathrm{~mL})$ and water $(100 \mathrm{~mL})$ and dried over $\mathrm{MgSO}_{4}$. After evaporation of the solvent, the residues were purified by chromatography: $\mathbf{5 a}-\mathbf{c}$ using $\mathrm{CHCl}_{3} /$ EtOAc $=1: 1$ as eluent and 5d using $\mathrm{CHCl}_{3} / \mathrm{EtOAc}=3: 1$ as eluent. Compound $\mathbf{5 b}$ was isolated as a solid in an overall yield of $68 \%: \mathrm{mp} 153-154^{\circ} \mathrm{C}$ (EtOAc) (lit. ${ }^{13} \mathrm{mp} 154-155^{\circ} \mathrm{C}$ ).

2,3-Dihydro-1-hydroxy-7-methoxy-1H-pyrrolo[1,2-a ]indole-9-carboxaldehyde (5a): overall yield $67 \% ; \mathrm{mp} 146-147$ ${ }^{\circ} \mathrm{C}$ (EtOAc); ${ }^{1} \mathrm{H}$ NMR $\delta 10.09$ (s, $\left.1 \mathrm{H}, \mathrm{CHO}\right), 7.44$ (d, $1 \mathrm{H}, J=$ $2.4 \mathrm{~Hz}, \mathrm{H}-8), 7.20$ (d, $1 \mathrm{H}, J=8.6 \mathrm{~Hz}, \mathrm{H}-5), 6.90$ (dd, $1 \mathrm{H}, J=$ 2.4 and $8.6 \mathrm{~Hz}, \mathrm{H}-6$ ), 5.60 (dd, $1 \mathrm{H}, J=6.3$ and $7.3 \mathrm{~Hz}, \mathrm{CHOH}$ ), $3.88\left(\mathrm{~s}, 3 \mathrm{H}, \mathrm{OCH}_{3}\right) ;{ }^{13} \mathrm{C} \mathrm{NMR} \delta 184.6(\mathrm{~d}, \mathrm{CHO}), 156.1(\mathrm{~s}, \mathrm{C}-7)$, 113.0 (d, C-6), 111.6 (d, C-5), 110.0 (s, C-9), 101.7 (d, C-8), 68.3 (d, $\mathrm{CHOH}), 55.8\left(\mathrm{q}, \mathrm{OCH}_{3}\right), 44.4\left(\mathrm{t}, \mathrm{NCH}_{2}\right)$; $\mathrm{RR}(\mathrm{KBr}) 1640(\mathrm{CHO})$ $\mathrm{cm}^{-1} ; \mathrm{MS}, \mathrm{m} / z\left(\mathrm{M}^{+}\right)$calcd 231.090 , found 231.089. Anal. $\left(\mathrm{C}_{13^{-}}\right.$ $\mathrm{H}_{13} \mathrm{NO}_{3}$ ) C, H, N.

6,7,8,9-Tetrahydro-9-hydroxy-2-methoxypyrido[1,2-a]indole-10-carboxaldehyde (5c): overall yield $69 \% ; \mathrm{mp}$ 138-139 ${ }^{\circ} \mathrm{C}$ (EtOH); ${ }^{1} \mathrm{H}$ NMR $\delta 10.12$ (s, $\left.1 \mathrm{H}, \mathrm{CHO}\right), 7.38$ (d, $1 \mathrm{H}, J=2.4$ $\mathrm{Hz}, \mathrm{H}-1$ ), 7.24 (d, $1 \mathrm{H}, J=8.9 \mathrm{~Hz}, \mathrm{H}-4), 6.92$ (dd, $1 \mathrm{H}, J=2.4$ and $8.9 \mathrm{~Hz}, \mathrm{H}-3), 5.25-5.0(\mathrm{~m}, 1 \mathrm{H}, \mathrm{CHOH}), 3.89\left(\mathrm{~s}, 3 \mathrm{H}, \mathrm{OCH}_{3}\right)$; ${ }^{13} \mathrm{C}$ NMR $\delta 184.8$ (d, CHO), 156.8 (s, C-2), 113.0 (d, C-3), 112.8 (s, C-10), 111.1 (d, C-4), 100.0 (d, C-1), 63.3 (d, CHOH), 55.8 (q, $\left.\mathrm{OCH}_{3}\right), 42.4\left(\mathrm{t}, \mathrm{NCH}_{2}\right)$; IR (KBr) $1630(\mathrm{CHO}) \mathrm{cm}^{-1} ; \mathrm{MS}, \mathrm{m} / z\left(\mathrm{M}^{+}\right)$ calcd 245.105, found 245.104. Anal. $\left(\mathrm{C}_{14} \mathrm{H}_{15} \mathrm{NO}_{3}\right) \mathrm{C}, \mathrm{H}, \mathrm{N}$.

6,7,8,9-Tetrahydro-9-hydroxy-2-methoxy-3-methylpyrido[1,2-a ]indole-10-carboxaldehyde (5d): overall yield $51 \% ; \mathrm{mp}$ 138-144 ${ }^{\circ} \mathrm{C} \operatorname{dec}\left(\right.$ EtOH) ; ${ }^{1} \mathrm{H}$ NMR $\delta 10.12$ (s, $1 \mathrm{H}, \mathrm{CHO}$ ), 7.30 (s, $1 \mathrm{H}, \mathrm{H}-1$ ), 7.09 (br s, $1 \mathrm{H}, \mathrm{H}-4), 5.25-5.0$ (m, $1 \mathrm{H}, \mathrm{CHOH}$ ), 3.91 (s, $\left.3 \mathrm{H}, \mathrm{OCH}_{3}\right), 2.33\left(\mathrm{~s}, 3 \mathrm{H}, \mathrm{CH}_{3}\right) ;{ }^{13} \mathrm{C} \mathrm{NMR} \delta 184.8(\mathrm{~d}, \mathrm{CHO})$, 155.4 (s, C-2), 113.0 (s, C-10), 111.7 (s, C-4), 97.9 (d, C-1), 63.3 (d, $\mathrm{CHOH}), 55.7\left(\mathrm{q}, \mathrm{OCH}_{3}\right), 42.5\left(\mathrm{t}, \mathrm{NCH}_{2}\right) ; \mathrm{IR}(\mathrm{KBr}) 1640(\mathrm{CHO})$ $\mathrm{cm}^{-1}$; MS, $m / z\left(\mathrm{M}^{+}\right)$calcd 259.121 , found 259.119. Anal. $\left(\mathrm{C}_{15^{-}}\right.$ $\mathrm{H}_{17} \mathrm{NO}_{3}$ ) C, H, N

General Procedure for the Synthesis of the Quinones 7. To a solution of $5 \mathrm{a}-\mathbf{d}(14.7 \mathrm{mmol})$ in $\mathrm{CH}_{2} \mathrm{Cl}_{2}(360 \mathrm{~mL})$ was added dropwise a solution of $65 \% \mathrm{HNO}_{3}(3.6 \mathrm{~g})$. After stirring at room temperature for $1 \mathrm{~h}$, the reaction mixture was washed with a $\mathrm{NaHCO}_{3}$ solution $(2 \times 50 \mathrm{~mL})$ and brine $(50 \mathrm{~mL})$ and dried over $\mathrm{MgSO}_{4}$. After removal of the solvent, the crude nitrobenzenes were obtained and converted without purification into the corresponding aniline derivatives 6 .

To a solution of the crude nitrobenzene $(7.4 \mathrm{mmol})$ in $\mathrm{EtOH}$ $(420 \mathrm{~mL})$ and $3 \mathrm{M} \mathrm{HCl}(116 \mathrm{~mL})$ was added tin powder $(7.0 \mathrm{~g})$ and the resulting reaction mixture was stirred at room temperature for 2-4 $\mathrm{h}$ until no more starting material could be detected by TLC (EtOAc). Subsequently, a NaHCO 3 solution was added and the mixture was extracted with $\mathrm{CHCl}_{3}(3 \times 125 \mathrm{~mL})$. The combined extracts were filtered over Hyflo, washed with brine (100
$\mathrm{mL}$ ), and dried with $\mathrm{MgSO}_{4}$. Evaporation of the solvent afforded the crude aniline derivatives 6 . These amines 6 could be isolated, ${ }^{33}$ but were converted directly into the corresponding quinones 7 .

To a solution of $6 \mathbf{a}-\mathbf{d}(0.5 \mathrm{mmol})$ in acetone $(30 \mathrm{~mL})$ and 0.167 $\mathrm{M} \mathrm{KH}_{2} \mathrm{PO}_{4}(15 \mathrm{~mL})$ was added a solution of Fremy's salt $(0.6 \mathrm{~g}$, $2.2 \mathrm{mmol})$ in water $(30 \mathrm{~mL})$. The mixture was stirred at room temperature until the reaction had terminated (about 2-4 h) as followed from TLC $\left(\mathrm{CHCl}_{3} / \mathrm{EtOAc}=1: 1\right)$. Subsequently, water $(100 \mathrm{~mL})$ was added and the mixture was extracted with $\mathrm{CHCl}_{3}$ $(3 \times 50 \mathrm{~mL})$. The combined extracts were washed with brine $(2$ x $50 \mathrm{~mL}$ ) and dried with $\mathrm{MgSO}_{4}$. After removal of the solvent the resulting residue was purified by chromatography: $7 \mathbf{a}, \mathbf{b}$ with $\mathrm{CHCl}_{3} /$ EtOAc $=1: 1$ as eluent and 7c,d with $\mathrm{CHCl}_{3} / \mathrm{EtOAc}=3: 2$ as eluent. Compound $\mathbf{7 b}$ was isolated as a solid in an overall yield of $62 \%$ : $\mathrm{mp} 189-191{ }^{\circ} \mathrm{C}$ (EtOH) (lit. ${ }^{13} \mathrm{mp} 179-181^{\circ} \mathrm{C}$ ).

2,3,5,8-Tetrahydro-1-hydroxy-7-methoxy-5,8-dioxo- $1 H$ pyrrolo[1,2-a ]indole-9-carboxaldehyde (7a): overall yield $54 \%$; $\operatorname{mp} 223-223.5^{\circ} \mathrm{C}(\mathrm{MeOH}) ;{ }^{1} \mathrm{H}$ NMR $\delta 10.33(\mathrm{~s}, 1 \mathrm{H}, \mathrm{CHO}), 5.75$ $(\mathrm{s}, 1 \mathrm{H}, \mathrm{H}-6), 5.43(\mathrm{t}, 1 \mathrm{H}, J=7.1 \mathrm{~Hz}, \mathrm{CHOH}), 4.04(\mathrm{~s}, 1 \mathrm{H}, \mathrm{OH})$, $3.87\left(\mathrm{~s}, 3 \mathrm{H}, \mathrm{OCH}_{3}\right) ;{ }^{13} \mathrm{C}$ NMR $\delta 188.3(\mathrm{~d}, \mathrm{CHO}), 178.2$ and 178.1 (s, $\mathrm{C}=0$ ), 105.9 (d, C-6), $67.2(\mathrm{~d}, \mathrm{CHOH}), 56.8\left(\mathrm{q}, \mathrm{OCH}_{3}\right), 47.3$ $\left(\mathrm{t}, \mathrm{NCH}_{2}\right)$; IR $(\mathrm{KBr}) 1660(\mathrm{C}=0), 1635(\mathrm{CHO}) \mathrm{cm}^{-1}$; MS, $m / z$ $\left(\mathrm{M}^{+}\right)$calcd 261.064, found 261.062. Anal. $\left(\mathrm{C}_{13} \mathrm{H}_{11} \mathrm{NO}_{5}\right) \mathrm{C}, \mathrm{H}, \mathrm{N}$.

$1,4,6,7,8,9$-Hexahydro-9-hydroxy-2-methoxy-1,4-dioxopyrido[1,2-a ]indole-10-carboxaldehyde (7c): overall yield 66\%; $\mathrm{mp} 232-233^{\circ} \mathrm{C}(\mathrm{EtOH}) ;{ }^{1} \mathrm{H}$ NMR $\delta 10.47(\mathrm{~s}, 1 \mathrm{H}, \mathrm{CHO}), 5.75(\mathrm{~s}$, $1 \mathrm{H}, \mathrm{H}-3), 5.15-4.8(\mathrm{~m}, 1 \mathrm{H}, \mathrm{CHOH}), 4.45-4.35\left(\mathrm{~m}, 2 \mathrm{H}, \mathrm{NCH}_{2}\right)$, $3.86\left(\mathrm{~s}, 3 \mathrm{H}, \mathrm{OCH}_{3}\right) ;{ }^{13} \mathrm{C} \mathrm{NMR} \delta 189.4(\mathrm{~d}, \mathrm{CHO}), 178.8(\mathrm{~s}, \mathrm{C}=\mathrm{O})$, 159.9 (s, C-2), 106.8 (d, C-3), 62.2 (d, $\mathrm{CHOH}), 56.7$ (q, $\mathrm{OCH}_{3}$ ), 46.4 $\left(\mathrm{t}, \mathrm{NCH}_{2}\right)$; IR (KBr) 1660 and $1650(\mathrm{C}=\mathrm{O}), 1640(\mathrm{CHO}) \mathrm{cm}^{-1}$; MS, $m / z\left(\mathrm{M}^{+}\right)$calcd 275.079 , found 275.080 . Anal. $\left(\mathrm{C}_{14} \mathrm{H}_{13} \mathrm{NO}_{5}\right)$ $\mathrm{C}, \mathrm{H}, \mathrm{N}$.

1,4,6,7,8,9-Hexahydro-9-hydroxy-2-methoxy-3-methyl-1,4dioxopyrido[1,2-a ]indole-10-carboxaldehyde (7d): overall yield $62 \%$; mp $153-154{ }^{\circ} \mathrm{C}(\mathrm{EtOH}) ;{ }^{1} \mathrm{H}$ NMR $\delta 10.46$ (s, $1 \mathrm{H}, \mathrm{CHO}$ ), 5.3-5.15 (m, $1 \mathrm{H}, \mathrm{CHOH}), 3.88\left(\mathrm{~s}, 3 \mathrm{H}, \mathrm{OCH}_{3}\right), 1.99\left(\mathrm{~s}, 3 \mathrm{H}, \mathrm{CH}_{3}\right)$; ${ }^{13} \mathrm{C}$ NMR $\delta 189.5$ (d, CHO), 179.4 and $179.3(\mathrm{~s}, \mathrm{C}=\mathrm{O}), 62.2(\mathrm{~d}$, $\mathrm{CHOH}), 61.2\left(\mathrm{q}, \mathrm{OCH}_{3}\right), 46.4\left(\mathrm{t}, \mathrm{NCH}_{2}\right), 28.8\left(\mathrm{q}, \mathrm{CH}_{3}\right) ; \mathrm{IR}(\mathrm{KBr})$ $1660(\mathrm{C}=\mathrm{O}), 1630(\mathrm{CHO}) \mathrm{cm}^{-1} ; \mathrm{MS}, \mathrm{m} / z\left(\mathrm{M}^{+}\right)$calcd 289.095, found 289.094. Anal. $\left(\mathrm{C}_{15} \mathrm{H}_{15} \mathrm{NO}_{5}\right) \mathrm{C}, \mathrm{H}, \mathrm{N}$.

General Procedure for the Synthesis of the Quinone Diols 8 and Quinone Alcohol 18. Hydrogen was bubbled through a solution of the quinone carboxaldehydes $7(1.9 \mathrm{mmol})$ in dry THF $(200 \mathrm{~mL}$ ) to which was added $5 \% \mathrm{Pd} / \mathrm{C}$ (no more than $200 \mathrm{mg}$ ) until the solution was colorless. Then a solution of $\mathrm{NaBH}_{4}(550$ $\mathrm{mg}, 14.4 \mathrm{mmol})$ in dry $\mathrm{MeOH}(50 \mathrm{~mL})$ was slowly added and hydrogen bubbling was continued for $1.5 \mathrm{~h}$. Subsequently, acetone ( $40 \mathrm{~mL}$ ) was added, the hydrogenation was stopped and nitrogen gas was passed through the reaction mixture for $10 \mathrm{~min}$. Finally, a $1 \mathrm{M} \mathrm{FeCl}_{3}$ solution in $0.1 \mathrm{M} \mathrm{HCl}(25 \mathrm{~mL})$ was added, and after stirring for $30 \mathrm{~min}$ the reaction mixture was filtered over Hyflo and extracted with $\mathrm{CHCl}_{3}(6 \times 100 \mathrm{~mL})$. The combined extracts were washed with brine $(2 \times 200 \mathrm{~mL})$ and dried with $\mathrm{MgSO}_{4}$. Evaporation of the solvent gave the almost pure quinone diols 8a-d, which were all purified by chromatography using EtOAc as eluent. Compound $\mathbf{8 b}$ was isolated as a solid ${ }^{34}$ in a yield of $90 \%$ : $\mathrm{mp} 166-168^{\circ} \mathrm{C}$ (lit. ${ }^{10 \mathrm{c}} \mathrm{mp} 164-165^{\circ} \mathrm{C}$ ). Compound $8 \mathrm{~b}$ gave no satisfactory elemental analysis but the purity was proven by the following TLC systems: silica gel, $\mathrm{CHCl}_{3} / \mathrm{EtOAc}=1: 1$ and $1: 3$, and $\mathrm{CHCl}_{3} / \mathrm{EtOH}=95: 5$ and $90: 10$.

2,3,5,8-Tetrahydro-1-hydroxy-9-(hydroxymethyl)-7-methoxy-1 $\boldsymbol{H}$-pyrrolo[1,2-a ]indole-5,8-dione (8a): yield $88 \% ; \mathrm{mp}$ $180-182^{\circ} \mathrm{C} ; 34,35{ }^{1} \mathrm{H}$ NMR $\delta 5.79(\mathrm{~s}, 1 \mathrm{H}, \mathrm{H}-6), 5.29$ and 4.51 (AB $\left.\mathrm{q}, 2 \mathrm{H}, J=5.3 \mathrm{~Hz}, \mathrm{CH}_{2} \mathrm{OH}\right), 4.4-4.1\left(\mathrm{~m}, 2 \mathrm{H}, \mathrm{NCH}_{2}\right), 3.77(\mathrm{~s}, 3$ $\left.\mathrm{H}, \mathrm{OCH}_{3}\right) ; \mathrm{MS}, \mathrm{m} / z\left(\mathrm{M}^{+}, \mathrm{C}_{13} \mathrm{H}_{13} \mathrm{NO}_{5}\right)$ calcd 263.079 , found 263.082 .

$1,4,6,7,8,9-$-Hexahydro-9-hydroxy-10-(hydroxymethyl)-2methoxypyrido $[1,2-a]$ indole-1,4-dione $(8 \mathrm{c})$ : yield $87 \% ; \mathrm{mp}$ $190-193{ }^{\circ} \mathrm{C} ; 34,35{ }^{1} \mathrm{H}$ NMR $\delta 5.77(\mathrm{~s}, 1 \mathrm{H}, \mathrm{H}-3), 5.27\left(\mathrm{AB} \mathrm{q},{ }^{36} 2 \mathrm{H}\right.$,

(33) The purification of for instance $6 \mathrm{a}$ has been described. ${ }^{12 b}$

(34) The compound could not be recrystallized, and consequently no satisfactory elemental analysis could be obtained.

(35) No satisfactory elemental analysis was obtained on account of instability of the compound. 
Table VI. Yields, Melting Points, Selected ${ }^{1}$ H NMR Data and Molecular Ion Values of 10-14, 17, and 19-21

\begin{tabular}{|c|c|c|c|c|}
\hline $\begin{array}{l}\text { com- } \\
\text { pound }\end{array}$ & $\underset{\%}{\text { yield, }}$ & $\begin{array}{c}\mathrm{mp},{ }^{\circ} \mathrm{C} \\
\text { (solv) }\end{array}$ & ${ }^{1} \mathrm{H} \mathrm{NMR}\left(\mathrm{CDCl}_{3}\right)^{b} \delta$ & $\begin{array}{c}\text { MS }\left(\mathrm{M}^{+}\right) \\
\text {found (calcd) }\end{array}$ \\
\hline $10 \mathbf{a}^{a}$ & 87 & $\begin{array}{l}170-171 \\
(\mathrm{MeOH})\end{array}$ & $\begin{array}{l}17(\mathrm{dd}, J=2.0 \text { and } 6.6 \mathrm{~Hz}, \mathrm{CHOAc}), 5.64(\mathrm{~s}, \mathrm{H}-6), 5.23\left(\mathrm{~s}, \mathrm{CH}_{2} \mathrm{O}\right), 4.5-4.1\left(\mathrm{~m}, \mathrm{NCH}_{2}\right) \text {, } \\
3.80\left(\mathrm{~s}, \mathrm{OCH}_{3}\right), 2.04 \text { and } 2.02\left(\mathrm{~s}, \mathrm{CH}_{3}\right)\end{array}$ & $7.100)$ \\
\hline $10 \mathbf{b}^{\circ}$ & 87 & $\begin{array}{l}140-141 \\
(\mathrm{EtOH})\end{array}$ & $\begin{array}{l}6.17(\mathrm{dd}, J=2.2 \text { and } 6.6 \mathrm{~Hz}, \mathrm{CHOAc}), 5.29\left(\mathrm{~s}, \mathrm{CH}_{2} \mathrm{O}\right), 4.03\left(\mathrm{~s}, \mathrm{OCH}_{3}\right), 2.07,2.05 \text {, and } 1.96 \\
\quad\left(\mathrm{~s}, \mathrm{CH}_{3}\right)\end{array}$ & $\begin{array}{l}361.114 \\
(361.116)\end{array}$ \\
\hline $10 \mathrm{c}^{a}$ & 78 & $\begin{array}{l}200-218^{\mathrm{c}} \\
(\mathrm{MeOH})\end{array}$ & $\begin{array}{l}6.35-6.1(\mathrm{~m}, \mathrm{CHOAc}), 5.69(\mathrm{~s}, \mathrm{H}-3), \approx 5.3\left(\mathrm{AB} \mathrm{q},{ }^{d} J \approx 7.2 \mathrm{~Hz}, 1 \mathrm{H}, \mathrm{CH}_{2} \mathrm{O}\right), 3.82\left(\mathrm{~s}, \mathrm{OCH}_{3}\right) \text {, } \\
2.06 \text { and } 2.03\left(\mathrm{~s}, \mathrm{CH}_{3}\right)\end{array}$ & $\begin{array}{l}361.116 \\
(361.116)\end{array}$ \\
\hline $10 \mathrm{~d}^{a}$ & 69 & $\begin{array}{l}179-180 \\
(\mathrm{MeOH})\end{array}$ & 6.3-6.15(m, CHOAc), $5.26\left(\mathrm{~s}, \mathrm{CH}_{2} \mathrm{O}\right), 4.01\left(\mathrm{~s}, \mathrm{OCH}_{3}\right), 2.06,2.04$, and $1.96\left(\mathrm{~s}, \mathrm{CH}_{3}\right)$ & $\begin{array}{l}375.132 \\
\quad(375.132)\end{array}$ \\
\hline $11^{e}$ & 57 & $\begin{array}{l}148-149 \\
(\mathrm{MeOH})\end{array}$ & $\begin{array}{l}6.17(\mathrm{dd}, J=2.2 \text { and } 6.6 \mathrm{~Hz}, \mathrm{CHOAc}), 5.28\left(\mathrm{~s}, \mathrm{CH}_{2} \mathrm{O}\right), 4.22\left(\mathrm{~s}, \mathrm{OCH}_{3}\right), 2.07 \text { and } 2.05(\mathrm{~s} \text {, } \\
\left.\mathrm{CH}_{3}\right)\end{array}$ & $\begin{array}{l}425.009 \\
(425.011)\end{array}$ \\
\hline $12^{a}$ & 5 & $\begin{array}{l}168-169^{c} \\
(\mathrm{MeOH})\end{array}$ & $6.35-6.2(\mathrm{~m}, \mathrm{CHOAc}), 5.25\left(\mathrm{~s}, \mathrm{CH}_{2} \mathrm{O}\right), 4.21\left(\mathrm{~s}, \mathrm{OCH}_{3}\right), 2.06$ and $2.04\left(\mathrm{~s}, \mathrm{CH}_{3}\right)$ & $\begin{array}{l}439.029 \\
(439.027)\end{array}$ \\
\hline $13 \mathbf{a}^{a}$ & 70 & $\begin{array}{l}202-203 \\
(\mathrm{EtOH})\end{array}$ & $\begin{array}{l}5.66(\mathrm{~s}, \mathrm{H}-6), 5.5-5.0(\mathrm{~m}, \mathrm{CHOH}), 5.29\left(\mathrm{~s}, \mathrm{OCH}_{2}\right), 4.45-4.2\left(\mathrm{~m}, \mathrm{NCH}_{2}\right), 3.82\left(\mathrm{~s}, \mathrm{OCH}_{3}\right), \\
\quad 3.4-3.0\left(\mathrm{~m}, \mathrm{NCH}_{2} \mathrm{CH}_{3}\right), 1.15\left(\mathrm{t}, J=7.4 \mathrm{~Hz}, \mathrm{CH}_{2} \mathrm{CH}_{3}\right)\end{array}$ & $\begin{array}{l}334.115 \\
\quad(334.117)\end{array}$ \\
\hline $13 \mathbf{b}$ & 57 & $\begin{array}{l}197-198 \\
(\mathrm{EtOH})\end{array}$ & $\begin{array}{l}5.5-5.0\left(\mathrm{~m}, \mathrm{CHOH} \text { and } \mathrm{CH}_{2} \mathrm{O}\right), 4.4-4.2\left(\mathrm{~m}, \mathrm{NCH}_{2}\right), 4.02\left(\mathrm{~s}, \mathrm{OCH}_{3}\right), 3.45-2.8\left(\mathrm{~m}, \mathrm{NCH}_{2} \mathrm{CH}_{3}\right) \text {, } \\
\quad 1.95\left(\mathrm{~s}, \mathrm{CH}_{3}\right), 1.09(\mathrm{t}, J=7.4 \mathrm{~Hz})\end{array}$ & $\begin{array}{l}348.131 \\
\quad(348.132)\end{array}$ \\
\hline $13 c^{a}$ & 5 & $\begin{array}{l}217-218^{c} \\
\quad \text { (acetone) }\end{array}$ & $\begin{array}{l}5.66(\mathrm{~s}, \mathrm{H}-3), 5.42 \text { and } 5.13\left(\mathrm{AB} \mathrm{q}, J=12.4 \mathrm{~Hz}, \mathrm{CH}_{2} \mathrm{O}\right), 5.3-5.0(\mathrm{~m}, \mathrm{CHOH}), 4.4-4.2(\mathrm{~m}, \\
\left.\mathrm{NCH}_{2}\right), 3.81\left(\mathrm{~s}, \mathrm{OCH}_{3}\right), 1.08\left(\mathrm{t}, J=7.2 \mathrm{~Hz}, \mathrm{CH}_{2} \mathrm{CH}_{3}\right)\end{array}$ & $3.132)$ \\
\hline $13 \mathbf{d}^{f}$ & 5 & $\begin{array}{l}216-218^{c} \\
\text { (acetone) }\end{array}$ & $\begin{array}{l}5.41 \text { and } 5.12\left(\mathrm{AB} \mathrm{q}, J=12.2 \mathrm{~Hz}, \mathrm{CH}_{2} \mathrm{O}\right), 5.25-5.0(\mathrm{~m}, \mathrm{CHOH}), 4.02\left(\mathrm{~s}, \mathrm{OCH}_{3}\right), 3.45-2.9 \\
\left(\mathrm{~m}, \mathrm{NCH}_{2} \mathrm{CH}_{3}\right), 1.96\left(\mathrm{~s}, \mathrm{CH}_{3}\right), 1.08\left(\mathrm{t}, J=7.3 \mathrm{~Hz}, \mathrm{CH}_{2} \mathrm{CH}_{3}\right)\end{array}$ & $\begin{array}{l}362.141 \\
\quad(362.140)\end{array}$ \\
\hline $14^{a}$ & 5 & $\begin{array}{l}99-100.5 \\
(\mathrm{EtOH})\end{array}$ & $\begin{array}{l}6.12(\mathrm{dd}, J=2.2 \text { and } 4.4 \mathrm{~Hz}, \mathrm{CHO}), 5.28\left(\mathrm{~s}, \mathrm{CH}_{2} \mathrm{O}\right), 4.4-4.2\left(\mathrm{~m}, \mathrm{NCH}_{2}\right), 4.02\left(\mathrm{~s}, \mathrm{OCH}_{3}\right) \text {, } \\
\quad 2.5-2.2\left[\mathrm{~m}, 2 \mathrm{C}(\mathrm{O}) \mathrm{CH}_{2}\right], 0.93\left(\mathrm{t}, J=7.1 \mathrm{~Hz}, \mathrm{CH}_{3}\right)\end{array}$ & $\begin{array}{l}417.176 \\
(417.179)\end{array}$ \\
\hline $17^{8}$ & 8 & $\begin{array}{l}160-162 \\
(\mathrm{EtOH})\end{array}$ & $\begin{array}{l}5.23\left(\mathrm{~s}, \mathrm{CH}_{2} \mathrm{O}\right), 4.22\left(\mathrm{t}, J=7.1 \mathrm{~Hz}, \mathrm{NCH}_{2}\right), 4.00\left(\mathrm{~s}, \mathrm{OCH}_{3}\right), 3.1-2.4\left(\mathrm{~m}, \mathrm{CH}_{2} \mathrm{CH}_{2}\right), 2.07 \text { and } \\
\quad 1.95\left(\mathrm{~s}, \mathrm{CH}_{3}\right)\end{array}$ & $\begin{array}{l}303.111 \\
(303.111)\end{array}$ \\
\hline $19^{a}$ & 9 & $\begin{array}{l}129-131 \\
(\mathrm{EtOH})\end{array}$ & $\begin{array}{l}6.08(\mathrm{dd}, J=2.1 \text { and } 6.5 \mathrm{~Hz}, \mathrm{CHOAc}), 4.4-4.2\left(\mathrm{~m}, \mathrm{NCH}_{2}\right), 4.01\left(\mathrm{~s}, \mathrm{OCH}_{3}\right), 2.30,2.07 \text {, and } \\
\quad 1.94\left(\mathrm{~s}, \mathrm{CH}_{3}\right)\end{array}$ & $\begin{array}{l}303.113 \\
(303.111)\end{array}$ \\
\hline $\mathbf{2 0}^{a}$ & 9 & $\begin{array}{l}151-152 \\
(\mathrm{EtOH})\end{array}$ & $\begin{array}{l}4.7-4.5\left(\mathrm{~m}_{1} \mathrm{OCH}_{2}\right), 4.54\left(\mathrm{~s}, \mathrm{CH}_{2} \mathrm{~S}\right), 4.35-4.1\left(\mathrm{~m}, \mathrm{NCH}_{2}\right), 4.00\left(\mathrm{~s}, \mathrm{OCH}_{3}\right), 1.93\left(\mathrm{~s}, \mathrm{CH}_{3}\right), 1.41 \\
\quad\left(\mathrm{t}, J=7.1 \mathrm{~Hz}, \mathrm{CH}_{3}\right)\end{array}$ & $\begin{array}{l}365.081 \\
\quad(365.076)\end{array}$ \\
\hline $21 a^{a}$ & 7 & $\begin{array}{l}187-189 \\
\quad(\text { EtOH })\end{array}$ & $\begin{array}{l}\text { 8.1-7.8 and 7.7-7.3 (m, PhH), } 7.27(\mathrm{~s}, \mathrm{H}-6), 6.5-6.2(\mathrm{~m}, \mathrm{CHOAc}), 4.55-4.35\left(\mathrm{~m}, \mathrm{CH}_{2} \mathrm{~S}\right) \\
\quad 4.3-4.1\left(\mathrm{~m}, \mathrm{NCH}_{2}\right), 3.82\left(\mathrm{~s}, \mathrm{OCH}_{3}\right), 2.02\left(\mathrm{~s}, \mathrm{CH}_{3}\right)\end{array}$ & $\begin{array}{l}425.089 \\
(425.093)\end{array}$ \\
\hline $21 b^{\alpha}$ & 73 & $\begin{array}{c}144-145 \\
(\mathrm{EtOH})\end{array}$ & $\begin{array}{l}6.34(\mathrm{dd}, J=2.0 \text { and } 6.5 \mathrm{~Hz}, \mathrm{CHOAc}), 5.67(\mathrm{~s}, \mathrm{H}-6), 4.59 \text { and } 4.36(\mathrm{AB} \mathrm{q}, J=14.0 \mathrm{~Hz} \text {, } \\
\left.\mathrm{CH}_{2} \mathrm{~S}\right), 4.4-4.1\left(\mathrm{~m}, \mathrm{NCH}_{2}\right), 3.82\left(\mathrm{~s}, \mathrm{OCH}_{3}\right), 2.02\left(\mathrm{~s}, \mathrm{CH}_{3}\right)\end{array}$ & $\begin{array}{c}409.062 \\
(409.066)\end{array}$ \\
\hline
\end{tabular}

${ }^{a}$ Satisfactory elemental analyses $\left( \pm 0.4 \%\right.$ for $\mathrm{C}, \mathrm{H}$, and $\mathrm{N}$ ) were obtained, except for $11,13 \mathrm{~d}, 17,21 \mathrm{~b} .{ }^{b} \delta$ (ppm) with $\mathrm{Me}{ }_{4} \mathrm{Si}$ as internal standard. 'Decomposes. ' ${ }^{d}$ Part of $\mathrm{AB}$ q; the other part overlaps with $\mathrm{NCH}_{2}$ absorptions. ${ }^{e} \mathrm{C}$ : calcd, 47.91 ; found, 46.34 . $f \mathrm{C}$ : calcd, 59.66 ; found, 58.08. C: calcd, 63.36; found, 62.85 .

$\left.J=4.3 \mathrm{~Hz}, \mathrm{CH}_{2} \mathrm{OH}\right), 5.0-4.5\left(\mathrm{~m}, 4 \mathrm{H}, \mathrm{CH}_{2} \mathrm{OH},{ }^{37} \mathrm{CHOH}, 2 \times \mathrm{OH}\right)$, 4.4-3.75 (m, $\left.2 \mathrm{H}, \mathrm{NCH}_{2}\right), 3.76\left(\mathrm{~s}, 3 \mathrm{H}, \mathrm{OCH}_{3}\right) ; \mathrm{MS}, \mathrm{m} / \mathrm{z}\left(\mathrm{M}^{+}\right.$, $\mathrm{C}_{14} \mathrm{H}_{15} \mathrm{NO}_{5}$ ) calcd 277.095 , found 277.098 .

1,4,6,7,8,9-Hexahydro-9-hydroxy-10-(hydroxymethyl)-2methoxy-3-methylpyrido [1,2-a]indole-1,4-dione (8d): yield $90 \%$; $\mathrm{mp} 134-136^{\circ} \mathrm{C}(\mathrm{EtOH}) ;{ }^{1}{ }^{1} \mathrm{H}$ NMR $\delta 4.94$ and 4.68 (AB q, $\left.2 \mathrm{H}, J=13.5 \mathrm{~Hz}, \mathrm{CH}_{2} \mathrm{OH}\right), 5.1-4.9(\mathrm{~m}, 1 \mathrm{H}, \mathrm{CHOH}), 3.97(\mathrm{~s}, 3$ $\left.\mathrm{H}, \mathrm{OCH}_{3}\right), 1.94\left(\mathrm{~s}, 3 \mathrm{H}, \mathrm{CH}_{3}\right) ; \mathrm{MS}, m / z\left(\mathrm{M}^{+}\right)$calcd 291.111 , found 291.111. Anal. $\left(\mathrm{C}_{15} \mathrm{H}_{17} \mathrm{NO}_{5}\right) \mathrm{H}, \mathrm{N}$; $\mathrm{C}$ : calcd, 61.85 ; found, 59.60 .

2,3,5,8-Tetrahydro-1-hydroxy-7-methoxy-6,9-dimethyl- $1 H$ pyrrolo[1,2-a ]indole-5,8-dione (18). When $7 \mathrm{~b}$ was reacted under the above conditions, but with $250 \mathrm{mg}$ of $\mathrm{Pd} / \mathrm{C}$, in addition to $8 \mathrm{~b}$ compound 18 was formed and isolated after chromatography (EtOAc) as a solid in a yield of $32 \%: m p ~ 202-205^{\circ} \mathrm{C} \mathrm{dec} ;{ }^{34,35}{ }^{1} \mathrm{H}$ NMR $\delta$ 5.4-5.1 (br s, $1 \mathrm{H}, \mathrm{OH}), 4.5-4.1(\mathrm{~m}, 3 \mathrm{H}, \mathrm{CHOH}$ and $\mathrm{NCH}_{2}$ ), 3.99 (s, $3 \mathrm{H}, \mathrm{OCH}_{3}$ ), 2.33 and $1.93\left(\mathrm{~s}, 3 \mathrm{H}, \mathrm{CH}_{3}\right) ; \mathrm{MS}, \mathrm{m} / z$ $\left(\mathrm{M}^{+}, \mathrm{C}_{14} \mathrm{H}_{15} \mathrm{NO}_{5}\right)$ calcd 261.100 , found 261.101 .

General Procedure for the Synthesis of the Quinone Diacetates 10, the Quinone Dibutyrate 14, and the Quinone Monoacetates 17 and 19. To a solution of the starting quinones 8,9 , and $18(1.8 \mathrm{mmol})$, triethylamine $(0.35 \mathrm{~g}, 3.4 \mathrm{mmol})$, and a catalytic amount of DMAP $(0.02 \mathrm{~g}, 0.2 \mathrm{mmol})$ in $\mathrm{CH}_{2} \mathrm{Cl}_{2}(100 \mathrm{~mL})$ was added dropwise a solution of acetic anhydride or butyryl chloride $(5.3 \mathrm{mmol})$ in $\mathrm{CH}_{2} \mathrm{Cl}_{2}(10 \mathrm{~mL})$. When the reaction was complete $(1-4 \mathrm{~h})$ as indicated by TLC (EtOAc), the solution was poured into a mixture of $2 \mathrm{M} \mathrm{HCl}$-ice $(100 \mathrm{~mL})$ and stirred for $1 \mathrm{~h}$. The layers were separated, and the organic layer was washed with a $\mathrm{NaHCO}_{3}$ solution $(100 \mathrm{~mL})$. After drying with $\mathrm{MgSO}_{4}$ the solvent was removed in vacuo and the residue was purified over Florisil: $10 \mathbf{a}, \mathbf{b}$ with $\mathrm{CHCl}_{3} /$ EtOAc $=5: 1$ as eluent, 10c,d and 14 with $\mathrm{CHCl}_{3} /$ EtOAc $=1: 1$ as eluent, and 17 and 19 with

(36) The other part of the $\mathrm{AB}$ q overlaps with the $\mathrm{CHOH}$ and $\mathrm{OH}$ absorptions.

(37) This part of the $\mathrm{AB} q$ system is situated at approximately $\delta 4.5$.

(38) Liskamp, R. J. M.; Colstee, J. H.; Ottenheijm, H. C. J.; Lelieveld, P.; Akkerman, W. J. Med. Chem. 1984, 27, 301.
$\mathrm{CHCl}_{3} /$ EtOAc $=95: 5$ as eluent. The yields, melting points, ${ }^{1} \mathrm{H}$ NMR data, and molecular ion values $\left(\mathrm{M}^{+}\right)$are given in Table VI.

1-(Acetyloxy)-9-[(acetyloxy) methyl]-6-bromo-2,3-dihydro-7-methoxy- $1 H$-pyrrolo[1,2-a ]indole-5,8-dione (11) and 9-(Acetyloxy)-10-[(acetyloxy)methyl]-3-bromo-6,7,8,9-tetrahydro-2-methoxy-1,4-dioxopyrido[1,2-a ]indole (12). A solution of $10 \mathrm{a}, \mathrm{c}(0.3 \mathrm{mmol})$ in acetic acid $(37.5 \mathrm{~mL})$ containing sodium acetate trihydrate $(3.3 \mathrm{~g}, 5.0 \mathrm{mmol})$ was treated with a solution of bromine $(63.9 \mathrm{mg}, 0.4 \mathrm{mmol})$ in acetic acid $(1.8 \mathrm{~mL})$. The mixture was stirred in the dark for $2.5 \mathrm{~h}$ whereupon ice water $(40$ $\mathrm{mL}$ ) was added. The resulting reaction mixture was extracted with $\mathrm{CH}_{2} \mathrm{Cl}_{2}(3 \times 75 \mathrm{~mL})$, and the combined extracts were washed with a $\mathrm{NaHCO}_{3}$ solution $(3 \times 50 \mathrm{~mL})$ and dried with $\mathrm{MgSO}_{4}$. After evaporation of the solvent, the residue was purified by chromatography: 11 with $\mathrm{EtOAc} / \mathrm{pe}=1: 1$ as eluent and 12 with $\mathrm{CHCl}_{3} /$ EtOAc $=5: 3$ as eluent. The yields, melting points, ${ }^{1} \mathrm{H}$ NMR data, and molecular ion values $\left(\mathrm{M}^{+}\right)$are given in Table VI.

General Procedure for the Synthesis of the Monocarbamates 13. To a solution of the quinone diol $8(0.9 \mathrm{mmol})$ and triethylamine $(2 \mathrm{~mL}, 25.3 \mathrm{mmol})$ in $\mathrm{CH}_{2} \mathrm{Cl}_{2}(30 \mathrm{~mL})$ was added ethyl isocyanate $(2 \mathrm{~mL}, 25.3 \mathrm{mmol})$. After stirring for $4 \mathrm{~h}$, the reaction mixture was washed with a $\mathrm{NH}_{4} \mathrm{Cl}$ solution $(2 \times 30 \mathrm{~mL})$ and dried over $\mathrm{MgSO}_{4}$. After removal of the solvent the residue was subjected to chromatography: $13 \mathrm{a}$ with $\mathrm{CHCl}_{3} / \mathrm{EtOAc}=2: 3$ as eluent and $13 \mathbf{b}-\mathbf{d}$ with $\mathrm{CHCl}_{3} / \mathrm{EtOAc}=1: 1$ as eluent. The yields, melting points, ${ }^{1} \mathrm{H}$ NMR data, and molecular ion values $\left(\mathrm{M}^{+}\right)$are given in Table VI. Compound $13 \mathrm{~d}$ gave no satisfactory elemental analysis but the purity was proven by the following TLC systems: silica gel, $\mathrm{CHCl}_{3} / \mathrm{EtOAc}=1: 1$ and 1:3, and $\mathrm{CHCl}_{3} / \mathrm{EtOH}$ $=95: 5$ and $90: 10$.

10-[(Acetyloxy)methyl]-6,7,8,9-tetrahydro-9-hydroxy-2. methoxypyrido[1,2-a ]indole-1,4-dione (15). A solution of quinone diol $8 \mathbf{c}(0.16 \mathrm{~g}, 0.58 \mathrm{mmol})$ and pyridine $(3 \mathrm{~mL})$ in $\mathrm{CH}_{2} \mathrm{Cl}_{2}$ $(30 \mathrm{~mL})$ was treated with a solution of acetic anhydride $(0.13 \mathrm{~g}$, $1.3 \mathrm{mmol})$ in $\mathrm{CH}_{2} \mathrm{Cl}_{2}(7 \mathrm{~mL})$. After stirring for 7 days, the solution was worked up as described for the quinone diacetates 10 (vide supra) to give 15 after chromatography using $\mathrm{CHCl}_{3} / \mathrm{EtOAc}=$ $1: 1$ as eluent in a yield of $49 \% ; \mathrm{mp} 176-177.5^{\circ} \mathrm{C}(\mathrm{MeOH}) ;{ }^{1} \mathrm{H}$ 
NMR $\delta 5.67(\mathrm{~s}, 1 \mathrm{H}, \mathrm{H}-3), 5.44$ and $5.26(\mathrm{AB} \mathrm{q}, 2 \mathrm{H}, \mathrm{J}=12.0 \mathrm{~Hz}$, $\left.\mathrm{CH}_{2} \mathrm{O}\right), 4.8-4.4(\mathrm{~m}, 1 \mathrm{H}, \mathrm{CHOH}), 4.15-3.8\left(\mathrm{~m}, 2 \mathrm{H}, \mathrm{NCH}_{2}\right), 3.81$ $\left(\mathrm{s}, 3 \mathrm{H}, \mathrm{OCH}_{3}\right), 2.05\left(\mathrm{~s}, 3 \mathrm{H}, \mathrm{CH}_{3}\right) ; \mathrm{MS}, \mathrm{m} / z\left(\mathrm{M}^{+}\right)$calcd 319.106 , found 319.105. Anal. $\left(\mathrm{C}_{16} \mathrm{H}_{17} \mathrm{NO}_{6}\right) \mathrm{C}, \mathrm{H}, \mathrm{N}$.

1-(Acetyloxy)-9-[(acetyloxy)methyl]-7-(1-aziridinyl)-2,3dihydro-6-methyl-1 $H$-pyrrolo[1,2-a ]indole-5,8-dione (16). A solution of $10 \mathrm{~b}(60.0 \mathrm{mg}, 0.2 \mathrm{mmol})$ in dry methanol $(80 \mathrm{~mL})$ was treated with aziridine $(2 \mathrm{~mL})$, and after stirring for $3 \mathrm{~h}$ at room temperature, the reaction mixture was left at $-20^{\circ} \mathrm{C}$ overnight. The precipitate was collected by filtration to afford 16 in a yield of 50\%: mp $210.5-211.5^{\circ} \mathrm{C}(\mathrm{EtOH}) 3^{35}{ }^{1} \mathrm{H}$ NMR $\delta 6.15(\mathrm{dd}, 1 \mathrm{H}$, $J=1.9$ and $6.6 \mathrm{~Hz}, \mathrm{CHOAc}), 5.29\left(\mathrm{~s}, 1 \mathrm{H}, \mathrm{CH}_{2} \mathrm{O}\right), 2.31(\mathrm{~s}, 3 \mathrm{H}$, $\left.\mathrm{CH}_{3}\right), 2.06\left[\mathrm{~s}, 6 \mathrm{H}, \mathrm{C}(\mathrm{O}) \mathrm{CH}_{3}\right]$; $\mathrm{MS}, m / z\left(\mathrm{M}^{+}\right)$calcd 372.132 , found 372.129. Anal. $\left(\mathrm{C}_{19} \mathrm{H}_{20} \mathrm{~N}_{2} \mathrm{O}_{6}\right) \mathrm{H}, \mathrm{N}$; $\mathrm{C}$ : calcd, 61.28 ; found, 60.48 .

General Procedure for the Reactions of the Mitosenes 10a and 17 with Potassium Ethyl Xanthate and Potassium Thiobenzoate under Reductive Conditions. A solution of 10a and $17(0.17 \mathrm{mmol})$ in a mixture of $\mathrm{CH}_{2} \mathrm{Cl}_{2} / \mathrm{MeOH} / \mathrm{H}_{2} \mathrm{O}=1: 1: 1$ $(50 \mathrm{~mL})$ was purged with $\mathrm{N}_{2}(10 \mathrm{~min})$ at room temperature. Subsequently, potassium ethyl xanthate or thiobenzoate $(0.85$ mmol) was added followed by a solution of $\mathrm{Na}_{2} \mathrm{~S}_{2} \mathrm{O}_{4}(60.0 \mathrm{mg}, 0.34$ $\mathrm{mmol})$ in water $(1 \mathrm{~mL})$. After the mixture was stirred for about $10 \mathrm{~min}$, the reaction was complete and reoxidation by air had taken place. The reaction mixture was extracted with $\mathrm{CH}_{2} \mathrm{Cl}_{2}(3 \times 50$ $\mathrm{mL}$ ), the organic phase was dried over $\mathrm{MgSO}_{4}$, and the solvent was removed in vacuo to give the crude compounds 20 and $21 \mathbf{a}, \mathbf{b}$, which were purified by chromatography using $\mathrm{CHCl}_{3} / \mathrm{EtOAc}=$ 1:1 as eluent. The yields, melting points, ${ }^{1} \mathrm{H}$ NMR data, and molecular ion values $\left(\mathrm{M}^{+}\right)$are given in Table VI.

2,3,5,8-Tetrahydro-7-methoxy-6,9-dimethyl- $1 \mathrm{H}$-pyrrolo[1,2-a ]indole-5,8-dione (22). A solution of 17 and $19(21.0 \mathrm{mg}$, $0.04 \mathrm{mmol})$ in EtOH $(5 \mathrm{~mL})$ was treated with $\mathrm{NaBH}_{4}(7.6 \mathrm{mg}$, $0.20 \mathrm{mmol}$ ). After the mixture was stirred for $15 \mathrm{~min}$, reoxidation had taken place and water $(10 \mathrm{~mL})$ was added. The reaction mixture was extracted with $\mathrm{CH}_{2} \mathrm{Cl}_{2}(3 \times 10 \mathrm{~mL})$; the combined extracts were dried with $\mathrm{MgSO}_{4}$. After evaporation of the solvent and purification by chromatography $\left(\mathrm{CHCl}_{3}\right), 22$ was obtained in a yield of $50 \%: \mathrm{mp} 165-167^{\circ} \mathrm{C}$ (EtOH) (lit. ${ }^{20 \mathrm{~b}} \mathrm{mp} 164.5-167$ $\left.{ }^{\circ} \mathrm{C}\right)$.

Acknowledgment. We are grateful for financial support of this work by the Netherlands Cancer Foundation. The studies concerning the biological activities of the (modified) mitosenes were performed under the auspices of the Screening and Pharmacology Group of the European Organization for Research and Treatment of Cancer (EORTC). We express our gratitude to J. M. Visser and J. L. M. Vrielink for recording the NMR and T. W. Stevens for recording the mass spectra.

Registry No. 3a, 96631-74-2; 3b, 3188-31-6; 3c, 109049-95-8; 3d, 109049-96-9; ( \pm )-4a, 120386-14-3; ( \pm )-4a (alcohol), 120386-18-7;

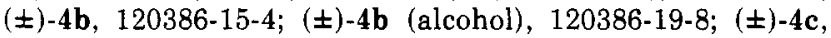
120386-16-5; ( \pm -4c (alcohol), 120386-20-1; ( \pm -4d, 120386-17-6;

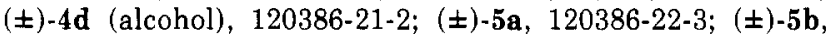
120386-23-4; ( \pm )-5c, 120386-24-5; ( \pm )-5d, 120386-25-6; ( \pm )-6a , 120386-30-3; ( \pm )-6a (nitro analogue), 120386-26-7; ( \pm )-6b, 120386-31-4; ( \pm )-6b (nitro analogue), 120386-27-8; ( \pm )-6c, 120386-32-5; ( \pm )-6c (nitro analogue), 120386-28-9; ( \pm )-6d, 120386-33-6; ( \pm )-6d (nitro analogue), 120386-29-0; ( \pm )-7a, 120386-34-7; ( \pm )-7b, 120386-35-8; ( \pm )-7c, 120386-36-9; ( \pm )-7d, 120386-37-0; $( \pm)-8 \mathbf{a}, 120386-38-1 ;( \pm)-8 \mathbf{b}, 120386-39-2 ;( \pm)-8 \mathbf{c}$, 120386-40-5; ( \pm )-8d, 120386-41-6; 9, 3188-26-9; ( \pm )-10a, 120386-

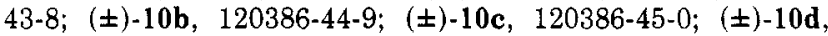
120386-46-1; ( \pm )-11, 120386-47-2; ( \pm )-12, 120386-48-3; ( \pm )-13a, 120386-49-4; ( \pm )-13b, 120386-50-7; ( \pm )-13c, 120386-51-8; ( \pm )-13d, $120386-52-9 ;( \pm)-14,120386-53-0 ;( \pm)-15,120386-58-5 ;( \pm)-16$, $120386-59-6 ; 17,3188-27-0 ;( \pm)-18,120386-42-7 ;( \pm)-19,120386$ 54-1; 20, 120386-55-2; ( \pm )-21a, 120386-56-3; ( \pm )-21b, 120386-57-4; ( \pm )-22, 66865-11-0; KSC(S)OEt, 140-89-6; KSC(O)Ph, 28170-13-0; aziridine, 151-56-4.

\title{
Highly Selective $\kappa$-Opioid Analgesics. 2. Synthesis and Structure-Activity Relationships of Novel $\boldsymbol{N}$-[(2-Aminocyclohexyl)aryl]acetamide Derivatives
}

\author{
Paul R. Halfpenny, Raymond G. Hill, David C. Horwell,* John Hughes, John C. Hunter, Stephen Johnson, ${ }^{\dagger}$ \\ and David C. Rees \\ Parke-Davis Research Unit, Addenbrookes Hospital Site, Hills Road, Cambridge, CB2 2QB, U.K. Received August 25, 1988
}

\begin{abstract}
This paper describes the chemical synthesis and the development of structure-activity relationships (SAR) for the $\kappa$ opioid receptor affinity and $\mu / \kappa$ opioid receptor selectivity of novel $N$-[(2-aminocyclohexyl)aryl]acetamide derivatives. The SAR of this series are investigated by consideration of structural modifications made to the aromatic moiety, the amide linkage, and cyclohexane and the pyrrolidine ring substituents of the prototype $\kappa$ selective agonist, PD117302 (trans- $N$-methyl- $N$-[2-(1-pyrrolidinyl)cyclohexyl] benzo[b]thiophene-4-acetamide) (1). The $k$ and $\mu$ opioid receptor binding affinities of 23 novel compounds are reported. It is observed that optimal $\mu / \kappa$ receptor selectivity is obtained with a benzo[b]thiophene aromatic system attached via the C-4 position, which is discussed in terms of steric and electronic parameters. The amide linkage has been replaced with the reversed amide, an ester, an aminomethylene, a thioamide, and a secondary amide. The best of these isosteres is the $N$-methyl amide. Substitution of the pyrrolidine ring of PD117302 in the 3-position with a hydroxymethylene group increases the $\mu / \kappa$ selectivity compared to the unsubstituted compound, e.g. compound 14, trans- $( \pm)-N$-methyl- $N$-[2-[3-(hydroxymethyl)-1-pyrrolidinyl]cyclohexyl]-4-benzo[b]furanacetamide monohydrochloride, $\mu / \kappa$ receptor selectivity $=244$. The cis fused, 4,5 dimethyl ether substituted cyclohexane analogue trans-( \pm )- $N$-methyl- $N$-[4,5-dimethoxy-2-(1-pyrrolidinyl)cyclohexyl]benzo[b]thiophene-4-acetamide monohydrochloride $(32)$ has high in vitro $\mathrm{k}$ opioid receptor affinity $\left(K_{\mathrm{i}}=16 \mathrm{nM}\right)$ and equipotent analgesic activity to morphine after iv administration in rats.
\end{abstract}

Previous studies ${ }^{1-7}$ have established that certain $N-[(2-$ aminocyclohexyl)aryl]acetamides exhibit high in vitro selectivity and affinity for the $\kappa$ opioid receptor and also elicit potent analgesia in rodent tests. For example, in part 1 of this work, ${ }^{1}$ compound 1 (PD 117302) has been shown

\footnotetext{
${ }^{\dagger}$ Chemistry Department, Warner Lambert-Parke Davis, Pharmaceutical Research Division, 2800 Plymouth Road, Ann Arbor, MI 48105.
}

to have nanomolar affinity for the $\kappa$ opioid receptor and a $\mu / \kappa$ ratio $\left[K_{\mathrm{i}}(\mu) / K_{\mathrm{i}}(\kappa)\right]=110$. The compound after oral

(1) Clark, C. R.; Halfpenny, P. R.; Hill, R. G.; Horwell, D. C.; Hughes, J.; Jarvis, T. C.; Rees, D. C.; Schofield, D. J. Med. Chem. 1988, 31, 831 .

(2) Von Voigtlander, P. F.; Lahti, R. A.; Ludens, J. H. J. Pharmacol. Exp. Ther. 1983, 224, 7 .

(3) Olson, G. A.; Olson, R. D.; Kastin, A. J.; Coy, D. H. Peptides $1982,3,1039$. 